IZA DP No. 9070

Information Frictions and Labor Market Outcomes

Ana Rute Cardoso

Annalisa Loviglio

Lavinia Piemontese

May 2015 


\title{
Information Frictions and Labor Market Outcomes
}

\author{
Ana Rute Cardoso \\ Institute for Economic Analysis (CSIC), \\ Barcelona GSE and IZA \\ Annalisa Loviglio \\ Universitat Autònoma de Barcelona \\ Lavinia Piemontese \\ Universitat Autònoma de Barcelona
}

Discussion Paper No. 9070

May 2015

IZA

P.O. Box 7240

53072 Bonn

Germany

Phone: +49-228-3894-0

Fax: +49-228-3894-180

E-mail: iza@iza.org

\begin{abstract}
Any opinions expressed here are those of the author(s) and not those of IZA. Research published in this series may include views on policy, but the institute itself takes no institutional policy positions. The IZA research network is committed to the IZA Guiding Principles of Research Integrity.

The Institute for the Study of Labor (IZA) in Bonn is a local and virtual international research center and a place of communication between science, politics and business. IZA is an independent nonprofit organization supported by Deutsche Post Foundation. The center is associated with the University of Bonn and offers a stimulating research environment through its international network, workshops and conferences, data service, project support, research visits and doctoral program. IZA engages in (i) original and internationally competitive research in all fields of labor economics, (ii) development of policy concepts, and (iii) dissemination of research results and concepts to the interested public.
\end{abstract}

IZA Discussion Papers often represent preliminary work and are circulated to encourage discussion. Citation of such a paper should account for its provisional character. A revised version may be available directly from the author. 


\section{ABSTRACT}

\section{Information Frictions and Labor Market Outcomes}

We analyze the impact of information frictions on workers' wages, contributing to the literature that tested search theory, which has so far focused on labor market frictions in general and not specifically on information asymmetries. Using data for 16 countries from the European Social Survey 2008, we find a sizeable gap between workers' perceptions of the unemployment rate and the actual unemployment rate in the country, which is a meaningful indicator of their misperception of labor market tightness. To handle the interval nature of our outcome of interest, the earnings variable, we estimate interval regressions, as well as ordered probit models. We follow a threefold strategy to tackle potential endogeneity problems, as the model includes: controls for the worker's ability; country-specific fixed effects; the unemployment rate in the region of residence, which might be the benchmark respondents have in mind when reporting their perception of the national unemployment rate and which is known to influence regional wages. Results show that when subjective perceptions overstate the unemployment rate in the country, a one percentage point gap between the perceived and the actual unemployment rate reduces individual wages by 0.4 to 0.7 percent. We discuss a potential mechanism generating this result. A pessimistic view of the labor market leads to concern over own future employment prospects and is thus likely to lower reservation wages; a too optimistic view, in turn, could raise reservation wages, but it would render job finding more difficult.

JEL Classification: J31, J42, J64

Keywords: job search, matching, unemployment, frictions, wage dispersion, labor market tightness

Corresponding author:

Ana Rute Cardoso

IAE-CSIC

Campus UAB

08193 Bellaterra

Spain

E-mail: anarute.cardoso@iae.csic.es

\footnotetext{
* We are grateful to David Card, Paulo Guimaraes, and Louis-Philippe Morin for their comments at different stages of this project. Cardoso acknowledges the support of the Spanish Ministry of the Economy and Competitiveness (grant ECO2012-38460 and the Severo Ochoa Programme for Centres of Excellence in R\&D SEV-2011-0075) and the Generalitat de Catalunya, grant 2014-SGR1414. She is a Research Fellow of IZA and MOVE. Loviglio acknowledges the support of La Caixa Fundation (La Caixa-Severo Ochoa International Doctoral Fellowship).
} 


\section{Introduction}

Labor market frictions prevent or delay the matching of job vacancies and unemployed workers. As such, they are responsible for the coexistence of firms with unfilled vacancies, looking for workers, and unemployed workers, looking for jobs. Candidate friction factors include mismatches between the skills required by jobs and those held by the unemployed, geographical mismatches, and obstacles to the flow of information about jobs (Pissarides, 2011: 1096). Such frictions lay at the core of the job search and matching literature and its path-breaking explanation of the functioning of the labor market, namely worker flows, unemployment and its duration, the wage distribution, or labor market policies.

The current analysis aims at testing the impact of information frictions on wages. Our analysis is conducted at the individual level, relying on a direct measure of labor market knowledge imperfections.

Stigler (1962) highlighted that information frictions lead to wage dispersion. Indeed, to the extent that workers have imperfect knowledge about jobs and wage offers, they must spend time, effort and, most likely, money to locate the highest wage paid for their services, among potential alternatives. Given that the amount of search required from workers to eliminate all wage dispersion would be too costly, wage differences will prevail in the economy. Moreover, in labor markets where demand and supply conditions fluctuate, the benefits of searching for information are reduced, because the information gathered will inevitably become obsolete. If so, workers will engage in less information search, which will feed into larger wage dispersion. Therefore, worker's knowledge of labor market conditions is crucial: "The information a man possesses on the labor market is capital: it was produced at the cost of search, and it yields a higher wage rate than on average would be received in its absence" (Stigler, 1962: 103).

Diamond (1971) challenged this result on wage dispersion as he showed that, in a world of homogeneous buyers and sellers ${ }^{1}$, the existence of search costs will give employers market power and, as a result, the wage distribution is expected to collapse into one single wage, at the monopsonist level. In other words, no employer would have an incentive to offer a wage above the workers' reservation wage. Fixing this

\footnotetext{
${ }^{1}$ Firms and workers, respectively, in this case.
} 
paradox and preserving the result on wage dispersion required additional assumptions, such as: heterogeneity in workers' search costs, the possibility to search while on the job, non-sequential job search, random variation in the number of job offers received, or heterogeneous propensity to search (see Mortensen (1999) and Baye et al. (2006) for an overview). The heterogeneity thus introduced across agents in their search costs, search efficiency or preferences translates into heterogeneous access to information on jobs and wages, which sustains a non-degenerate wage distribution.

Despite the early emphasis on information frictions, it has become standard in the labor literature to capture market frictions by defining the ratio $(k)$ of the rate of arrival of job offers $(\lambda)$ to the rate of job destruction $(\delta)$. This represents the average number of job offers a worker can expect to receive per event of job match destruction suffered, which will be larger in markets with fewer frictions. Labor market frictions are thus captured by the inverse of $k$. A clear link between this indicator and the wage level has been derived by Burdett and Mortensen (1998). They showed that the share of rents earned by workers relative to the firm decreases with the frictions indicator - if workers tend to receive less job offers, firms will face less competition when biding for workers and they will, therefore, manage to keep wages lower.

Ingenious as it is, this indicator nevertheless loses track of the sources of frictions. In particular, the rate of arrival of job offers bundles together: frictions such as skill mismatches, mobility costs, and lack of information on job requirements, on wages offered, or even on other workers' job application decisions, which may lead to congestion that lowers an individual's chances of receiving an offer; decisions such as job search intensity by the workers or vacancy advertisement by the firms; labor market tightness or average number of job vacancies per worker. Therefore, the specific impact of workers' information shortages on their wages can be obscured under this composite indicator. As Pissarides and Petrongolo argue, such is the price to pay for having stylized models: "Modeling each one of these [frictions] explicitly would introduce intractable complexities in macroeconomic models" (Petrongolo and Pissarides, 2001: 390).

The impact of information frictions specifically on price dispersion in the labor market has not been tested. ${ }^{2}$ Van den Berg and van Vuuren (2010) tested the impact

\footnotetext{
${ }^{2}$ For an overview of both the theoretical and empirical literature on information frictions and price dispersion,
} 
of labor market frictions on wages, but they were concerned with frictions in general and not those referring to information in particular. The first stage of their empirical analysis relies on three-year panel data on workers' labor market states, their durations, and the wage distribution. The likelihood of each possible sequence of labor market states is a function of the friction parameters, estimated by maximum likelihood. The second stage of the analysis evaluates the impact of the estimated frictions on average wages, exploiting variation in frictions and wages across regions and industries in Denmark. They find that, even though labor market frictions have a negative impact on wages, their role explaining wages in Denmark is small. Structural estimation of search models by other authors included the decomposition of wage dispersion into its sources, with diverging results. The model by Postel-Vinay and Robin (2002) assumed perfect information and decomposed wage dispersion into a firm effect, a person effect and the effect of labor market frictions. They found that frictions in general account for 50 percent of wage dispersion. Instead, Van der Berg and Ridder (1998) had decomposed the dispersion in wage offers into the effect of observables (education, age and occupation), of unobservables, of labor market frictions, and measurement error, finding that frictions account for at most 25 percent of the wage variance.

Our aim is to uncover the impact of workers' information imperfections about labor market conditions on their wages. We are thus focusing explicitly on one type of labor market friction and one outcome. We exploit information gathered by the European Social Survey (ESS), which included in its 2008 wave a question on the respondents' degree of information about the job market. More precisely, individuals were asked for an estimate of the unemployment rate in their country. We take the deviation between their answers and the actual unemployment rate in the country as the degree of misperception of the job market situation or labor market tightness. This index may be thought of as a measure of information frictions that is bound to affect individual behavior in the labor market. In particular, if a pessimistic view of the unemployment rate is associated with concern over becoming unemployed, it will influence workers' decisions, namely on the reservation wage, which would be set too low.

see Baye et al. (2006). An interesting example is Jensen (2007), who exploited the expansion of mobile phones in an Indian state to evaluate the impact of information costs on price dispersion in the fisheries market. 
The ESSE survey reveals that workers perceptions of labor market tightness, though related to the actual phenomenon, are remarkably imprecise. This evidence on widespread information frictions in the labor market is corroborate by (rare) surveys where this type of questions is asked (see Ipsos Mori, 2014). Nevertheless, evidence on its impact in the economy is lacking.

Our empirical strategy departs from the estimation of Mincer-augmented wage regressions, which include controls for the worker attributes, firm- and job-related attributes, and family demographics. Given that the outcome variable is measured in intervals, we estimate both interval regressions and ordered probit models. We tackle potential endogeneity problems that may affect our initial estimates. Indeed, if individual- or country-level unobserved factors that influence wage setting are correlated with the degree of information frictions in the labor market, our initial estimates will be biased. We adopt a threefold strategy to tackle this problem: controlling for the regional unemployment rate, which could influence individual's perceptions of the country unemployment rate and has been widely documented to be a determinant of wages, according to the wage curve literature (Blanchflower and Oswald, 1994); controlling for country fixed effects, which will capture any countrywide factors common to all individuals, such as the institutional setting, mobility costs or labor market tightness; controlling for worker ability, based on two proxy variables reported in the dataset by the survey interviewer.

Section 2 provides a theoretical motivation for our empirical work. Section 3 describes the data and the key variables used, while section 4 discusses specifically the indicator of labor market information frictions. The empirical models are introduced in section 5. Section 6 presents the results and discusses potential mechanisms. Finally, section 7 concludes.

\section{Theoretical motivation}

The basic job-search theory offers a suitable environment to spell our motivation for the empirical analysis that will be undertaken. ${ }^{3}$

As usual in this framework, we assume that in each period a worker searching for a job draws an offer $w$ from the wage offer distribution and decides whether to

\footnotetext{
${ }^{3}$ An overview can be found in chapter 6 of Ljungqvist and Sargent (2004) and chapter 5 of Cahuc, Carcillo and Zylberberg (2014).
} 
accept or reject it according to her expected future utility. The worker's discount factor is $\xi<1$. To keep things simple, we assume that the distribution of wage offers is constant over time and we abstract from the existence of unemployment benefits. The worker's maximization problem reduces to the comparison of the wage offer with her reservation wage $\underline{w}$, which depends on $\xi$ and on the shape of the wage offer distribution.

Let us posit that the unemployment rate can affect the expected wage in the economy: ${ }^{4}$

$$
w=h(u)+\epsilon, \quad E(\epsilon \mid u)=0
$$

where $h$ is decreasing with $u$ and the term $\epsilon$ follows a given distribution $F{ }^{5}$

Clearly, $P(w<W)=P(\epsilon<W-h(u))=F(W-h(u))$ and therefore the distribution of $\epsilon$ characterizes a distribution $F_{u}(w)=F(w-h(u))$ for the wage that depends on the parameter $u$. Given the parameter $u$, the worker's reservation wage $\underline{w}$ is implicitly characterized by the following expressions ${ }^{6}$ :

$$
\begin{aligned}
\underline{w} & =\frac{\xi}{1-\xi} \int_{\underline{w}}^{+\infty}(w-\underline{w}) d F_{u}(w) \\
& =\xi h(u)+\xi \int_{-\infty}^{\underline{w}} F(w-h(u)) d w
\end{aligned}
$$

Let us now consider a population of workers that differ only in their believes about the unemployment rate. Each agent $i$ has a prior that the unemployment rate is $v_{i}=u+s_{i}$, where the random variable $s_{i}$ measures the individual misperception. In the absence of additional information, a worker's best guess is to assume that the unemployment rate is $v_{i}$. Therefore, she assumes the distribution of wages is $F_{v_{i}}(w)=F\left(w-h\left(v_{i}\right)\right)$ and sets her reservation wage $\underline{w}_{i}$ accordingly.

This "misperception" of the unemployment rate causes a shift in the distribution of perceived wage offers with respect to the true distribution $F_{u}$. This shift is to the left if the unemployment is overestimated (namely $h\left(v_{i}\right)<h(u)$ ), while it is to the right if it is underestimated (namely $h\left(v_{i}\right)>h(u)$ ).

\footnotetext{
${ }^{4}$ The relationship between wages and the unemployment rate has been broadly debated in labor economics. Recently, Galí (2011) provided a theoretical foundation for the empirical evidence on the US of a negative correlation between wage inflation and unemployment rate in the last decades. For another perspective, dating further back, see Blanchflower and Oswald (1994). Given the illustrative purpose of this section, we abstract from this debate and rely on the simplifying assumptions described in the main text.

${ }^{5}$ We can assume the support of the distribution to be bounded below by some $B>-h(u)$. Alternatively, we can impose that $w$ follows a log-normal distribution $\log \mathcal{N}\left(\mu, \sigma^{2}\right), h(u)=E(W)=\exp \left(\mu+0.5 \sigma^{2}\right)$ and derive the following steps accordingly.

${ }^{6}$ For the derivations, refer back to Ljungqvist and Sargent (2004) and Cahuc, Carcillo and Zylberberg (2014).
} 
It is quite intuitive that a "pessimistic" worker who overestimates the unemployment rate will pick a reservation wage lower than $\underline{w}$ and vice-versa. A simple application of the implicit function theorem to the above expression confirms the intuition:

$$
\frac{\partial \underline{w}}{\partial u}=\frac{\xi h^{\prime}(u)\left(1-\int_{-\infty}^{\underline{w}} F^{\prime}(\underline{w}-h(u)) d w\right)}{1-\xi F(\underline{w}-h(u))}<0 .
$$

An increase in the unemployment rate parameter will decrease the reservation wage.

From now on, let us denote by $u$ the true unemployment rate in the economy and by $v$ an individual's perception of it (we omit the subscript $i$ for notational ease). The reservation wage $\underline{w}(u)$ obtained under the perfect knowledge of the unemployment rate, i.e. under the knowledge of the true distribution of wage offers, optimizes the life-time worker's expected utility. By definition, any other choice causes a welfare loss. In particular, a worker who overestimates the unemployment rate accepts wages that she should rather reject. Conversely, when the unemployment rate is underestimated, the worker rejects offers that would have been accepted under perfect information. As a consequence, her spell of unemployment is expected to last longer. To better clarify this last point, let $\lambda_{v}=\int_{-\infty}^{\underline{w}}(v) d F_{v}(w)$ be the probability of rejecting a job offer under the assumption that the unemployment rate is $v$. As discussed above, $v<u \Rightarrow \lambda_{v}>\lambda_{u}$, because of a higher reservation wage. Recall that the successive draws are independent, so that the waiting time $T_{v}$ is geometrically distributed and is given by

$$
T_{v}=\frac{1}{1-\lambda_{v}}
$$

which is an increasing function of $v$. Hence $v<u \Rightarrow T_{v}>T_{u}$.

Summarizing, agents with different reservation wages may end up in jobs paid differently. Indeed, if the types are private information, a firm cannot know the prospective employees' reservation wage and faces a trade-off between offering a higher wage to attract more workers in a shorter time, or paying a lower wage, which allows it to increase the per-worker profit, but may require a longer time to complete the matching because a smaller subset of the population is willing to accept it. General equilibrium results are out of the scope of the present illustration, but it is worth mentioning that, as opposed to the baseline case criticized by Diamond, this heterogeneity across agents may allow the resulting wage distribution to be non-degenerate ${ }^{7}$.

\footnotetext{
${ }^{7}$ The fact that heterogeneity of agents' reservation wage may guarantee a non degenerate distribution was first
} 


\section{Data set}

The European Social Survey (ESS) focuses on Europe's institutions and the attitudes, beliefs and behavior patterns of its population (ESS, 2008b: 3). It provides information at the individual level covering more than 30 countries, with 1,500 to 3,000 respondents per country. Six cross-sections of data are available, as the survey was implemented from 2002 to 2012 on a biennial basis. A core set of issues, common across rounds, is surveyed in each round. Additionally, a rotating section is devoted in each round to specific issues, which can be repeated in later rounds. The rotating section has focused on themes such as immigration, democracy, justice, economic morality, or welfare attitudes, among others. We rely on data from the 2008 round $^{8}$, which, under the "welfare attitudes" section, asked respondents for their perception of the unemployment rate in their country. Interviews for this round took place between 2007 and 2009. Within each country, interviews may span over a few months.

Information on each household is provided by one respondent, aged 15 or over. When more than one person is eligible, the respondent is randomly selected, based on one of two alternative procedures: either all eligible residents are listed in alphabetical order of first name or in age order to be assigned a rank number, which is used to choose the respondent from a grid that matches the number of people in the household to the respondent's rank number; or the adult who last celebrated her birthday is selected (ESS 2008b: 11-13).

Information on the ability of the respondent to understand the questions is provided by the interviewer, who answers two questions on whether the respondent understood the questions and whether he asked for clarification on any questions.

The data source reports design weights, meant to correct for unequal probabilities of being selected into the survey, as a result of the stratification procedure designed. It also provides population size weights, meant to adjust the sample size of each country to its relative population size, whenever the analysis pools data on different countries to detect an overall pattern. Moreover, the data producer provides post-stratification weights, which mainly correct the initial design weights for non-

shown by Albrecht and Axell (1984).

${ }^{8}$ In the terminology of the data producer, we have used the Integrated File that merges all countries with comparable data, edition 4.3 . 
response; they aim at guaranteeing that the proportions of respondents with certain characteristics - age group, gender, education, and region - match known population values. These weights are required whenever non-response systematically affects respondents with specific attributes, or when the initial survey had itself problems of coverage of the population (for details on the weighting scheme, see ESS (2014)). Unless otherwise stated, all computations use the ESS post-stratification weights combined with population size weights.

Two questions in the survey are of particular relevance for the analysis to be undertaken: the household income and the perceived unemployment rate reported by the survey respondent. The latter will be the object of section 4 below. We will describe in detail the restrictions imposed on the dataset to focus the analysis on labor earnings of the main household labor earner.

\section{Income variable}

The outcome of interest - labor income - is captured by the following question in the ESS 2008: "Using this card, please tell me which letter describes your household's total income, after tax and compulsory deductions, from all sources? If you don't know the exact figure, please give an estimate. Use the part of the card that you know best: weekly, monthly or annual income" (ESS, 2008c: 60). The reported net income thus refers to all sources earned by all household's members and it is coded as country-specific income deciles. Each respondent was shown a card with the upper and lower bounds of each income decile in the country, defined in the local currency; the ESS documentation provides the boundaries for each interval (EES, 2008d).

It is well-known that survey respondents are particularly reluctant to reveal their income and, as a result, non-response is usually acute for this type of questions. There is also concern over income misreporting, which is more likely whenever one single question on the total household income is asked, instead of a separate question on each income component and earner (Hoffmeyer-Zlotnik and Waner, 2006; Micklewright and Schnepf, 2010), or when the respondent is not the main income earner in the household.

Our first check on the income variable consisted on excluding countries whose income data was not collected in a comparable way: Bulgaria, Cyprus, Slovakia, 
and Turkey (ESS 2010: 14,15,20,21). We have as well excluded countries where a major share of the households did not report their income. This particular item non-response affected over one fourth of the respondents in the following countries: Croatia, Czech Republic, Greece, Israel, Portugal, Spain, and Switzerland, which were therefore dropped from the analysis. ${ }^{9}$

Observations with missing income were naturally excluded from the analysis. The second check on the income variable thus aimed at detecting whether income non-response was subject to any systematic pattern. We modeled the probability that income for a household is non-missing, as a function of its respondent's gender, age, education, and labor market status, as well as the household main source of income (see table 5 in appendix for the results). There is no significant difference in the propensity to report the household income across gender of the respondent. However, we find, as expected, that respondents who are not in paid employment (in particular students) are less likely to report the income of their households. By the way, we would expect that if these respondents were to report income, they would do so less reliably, introducing measurement error into the analysis. The other major pattern concerns the impact of the household's main source of income. Households whose main income source is self-employment are less likely to report their income, with the opposite holding for households whose main income originates in social benefits. The results in table 5 are very robust across countries (not reported). This type of concerns over non-response, together with the aims of our analysis of the labor market, will determine below the constraints to be imposed on the analysis sample.

Finally, the third procedure to check the income data considers whether, after using the post-stratification weights defined by the ESS, the households are uniformly distributed across income deciles, with 10 percent falling on each decile, as conceptually they should. We find that is not the case ${ }^{10}$, as indeed the data producer itself acknowledges: "The variable [household income] for the different countries deviates to varying degrees from the expected decile distribution" (ESS, 2010: 14). Combining the second and third data checks, we have indication that data on income

\footnotetext{
${ }^{9}$ We used weighted data when computing these percentage of item non-response.

${ }^{10}$ Formal tests show that the distribution of the surveyed population by income deciles does not fit the uniform distribution, for every country except Denmark, for whom the null hypothesis is not rejected (at the $5 \%$ significance level). These results are available from the authors upon request.
} 
may be missing in a non-random way that is not fully corrected by the ESS poststratification weights. Under the assumption that the income intervals that were shown the respondents indeed correspond to the deciles of the country's household income distribution in the reference year, we would want to consider an alternative weighting scheme that guarantees a uniform distribution of the sampled households across income deciles. Appendix A provides the explanation of such an alternative weighting scheme.

Nevertheless, there are plausible reasons why the income intervals that were shown the respondents may deviate from the true deciles of the country's household income distribution in the reference year, such as: the income brackets do not refer to the survey year, but to an earlier period, and they have not been adjusted for inflation or changes in tax and social transfers rates; the deciles were computed from general surveys that did not have income (expenditures, poverty or living conditions, more generally) as its specific object; the concept of income may differ between the two data sources. If so, the deciles could themselves be measured with error, despite the data protocol effort to avoid this possibility (see the instructions in ESS (2008a: 17)). In such cases, the income brackets shown the respondents will still provide a meaningful partition of the population into ordered income categories, despite the fact that they cannot be called income deciles. In this case, it would be advisable to refrain from implementing any reweighting of the data beyond the ESS post-stratification weights, as the correction that would allocate 10 percent of the population to each of these brackets would be departing from a wrong assumption on the true distribution of the population.

Given that there is no unambiguous advantage of one weighting scheme over the other, we will perform the analysis using the two alternatives - the original ESS post-stratification weights and the new weights designed to guarantee a uniform distribution of the overall population across income deciles — and check the robustness of our results. ${ }^{11}$

Yet another possibility is that income perceived and reported by the respondent may deviate from the true household income. If so, we would not expect to find

\footnotetext{
${ }^{11}$ We have not attempted to impute income, a procedure followed for example by the OECD (2013) in the SILC dataset, because it would require additional information that is not available in the cross-section ESS (HoffmeyerZlotnik and Waner, 2006: 299). In particular, longitudinal data would allow for measurement and correction of non-response in a more accurate way, as information on some waves could be used to infer missing information in other waves.
} 
a uniform distribution of reported income across the brackets defined. Again, this situation corroborates the idea that none of the weighting procedures is unambiguously more adequate than the other. By relying on both alternatives, we can check the robustness of our results. Note also that the data restrictions that will be imposed to focus the analysis on earnings by the main household earner guarantee that measurement error in earnings is minimized (by analyzing earnings information reported by the main household earner himself, in households that do not have other sources of income).

\section{Analysis sample}

The analysis relies on the following countries: Belgium, Denmark, Estonia, Finland, France, Germany, Hungary, Ireland, Latvia, The Netherlands, Norway, Poland, Romania, Slovenia, Sweden and the United Kingdom. For Ukraine and Russia, no data on monthly unemployment rate could be compiled and therefore these countries are not part of the analysis. The initial sample includes 24,310 observations on 16 countries.

Our goal is to quantify the impact of the unemployment misperception by the respondent on his labor income, in the spirit of a worker level wage regression. However, the survey provides information on the total income of the household. Such value will coincide with the respondent's labor income if he is the single wage earner in a household that does not benefit from other sources of income. We therefore imposed a set of constraints on the sample to be analyzed.

We first restricted the analysis sample to households whose main source of income is wages or salaries (dropping $39 \%$ of the initial sample: $25 \%$ referring to pensions, $5 \%$ to income from self-employment, and the remaining $9 \%$ to unemployment benefits, other social benefits or grants, income from investments or savings, from farming, or from unspecified sources). Secondly, we restricted analysis to households whose respondent's main activity is paid work (dropping $14 \%$ of the observations) and whose employment relationship is a labor contract (employee, thus excluding the self-employed or those working for a family business, $3 \%$ of the observations). As a third constraint, we concentrate on households consisting of the respondent and, for multi-person households, the partner and/or children below age 16. This excluded $14 \%$ of the observations, the large majority of them households 
where the respondent was the offspring of other household members. This restriction fulfills a twofold purpose. On one hand, we include only households whose members' economic activity and thus income source can be identified, given that the survey provides such information for the respondent and the partner, but not other household members (who could be recipients of unemployment benefits, disability benefits, early retirement pensions, etc.). On the other hand, we aim at reducing the extent of income misreporting, more likely to occur when the respondent is not the main income earner, but instead his offspring. ${ }^{12}$ The fourth constraint aims at purging the dataset of any pension or old-age benefits and we thus dropped households with members aged 65 or older ( $0.7 \%$ of the observations). Finally, we kept only households where the partner does not work for the market (is a houseperson), dropping $20 \%$ of the observations. As such, we guarantee that the respondent is the single wage-earner, for whom we can thus estimate a wage function.

The final analysis sample comprises 2,310 observations on the 16 countries, after excluding observations with missing information on perceived unemployment ( $3 \%$ of the observations). Table 1 provides descriptive statistics. The average gap between the perceived and the actual unemployment rate is 15 percentage points. Whereas the majority of the individuals overestimate the unemployment rate, thus having a pessimistic view of the labor market, 19 percent underestimate it. In any case, the latter group has a remarkably more accurate view of the labor market, as their average misperception of the unemployment rate is down to 2 percentage points (in absolute value). Note that the sample is rather balanced in terms of gender: $59 \%$ males and $41 \%$ females. The average age of respondents is 40 years. A share of $40 \%$ completed tertiary education, whereas $43 \%$ completed upper secondary education. An ability indicator derived from the interviewer's appraisal indicates that $77 \%$ of the respondents never or almost never required clarifications to the questions being asked (ability2) and 96\% understood the questions very often or often (ability1). The firm size distribution points to a certain concentration of employment in: small and medium-sized firms (the omitted category), with 59\% of employment; the services, with $67 \%$ of employment. Ten percent of the workforce works part-time and $83 \%$ are on an open-ended contract; $26 \%$ are affiliated with a trade union.

\footnotetext{
${ }^{12}$ We dropped as well four households where the respondent declared two members of the household as his/her partner.
} 
The analysis sample is a small subset of the initial one. Whereas it is most likely not representative of the households in the economy, it is constructed to be representative of the wage-earner population. We can have an indication as to whether this aim was accomplished by comparing, in section 6 , the estimates on the coefficients of the control variables in the wage regression to the benchmarks in the previous literature.

\section{The indicator of information frictions}

\section{Perceived unemployment rate}

Respondents in the ESS 2008 were asked to provide an estimate of the unemployment rate in their country, under the exact phrasing: "Of every 100 people of working age in your country how many would you say are unemployed and looking for work? Choose your answer from this card. If you are not sure please give your best guess" (ESS, 2008c: 25). ${ }^{13}$ Respondents were shown 11 intervals to choose from, with the first ten having a common width (0-4, 5-9, and so forth up to 45-49), and the final one reading "50 or more".

\section{Index of unemployment misperception}

The degree of information frictions existing in the labor market will be captured by the discrepancy between the perceived unemployment rate declared by the survey respondent and the actual unemployment rate in the country the month the interview took place. ${ }^{14}$ The monthly unemployment rate was collected from Eurostat (2013).

We computed the unemployment misperception as:

$$
u g a p=m([a, b])-u,
$$

where $[a, b]$ stands for the bracket of perceived unemployment rate, $m$ is its midpoint, considered as the representative value, and $u$ is the actual unemployment rate in the country at the reference moment (for details on interval arithmetic, see Moore et al., 2009).

\footnotetext{
${ }^{13}$ Working age: the age from which people are legally entitled to work up to retirement age. Unemployed: people who cannot find paid work (ESS, 2008c: 25). We disregard the subtlety that the total population is the denominator respondents were asked to consider, instead of the active population, as we believe the question was phrased in the simplest and least technical way possible to capture the respondent's perception of the unemployment rate.

${ }^{14}$ Defined as the start of the interview (which coincides with the end moment in virtually all cases). We dropped one observation with inconsistent dates for start and end of interview.
} 
Figure 1 reports this gap between the perceived and actual unemployment rates. Interestingly, in every country, an overwhelming majority of the working population overestimates the unemployment rate. Nevertheless, there are striking differences across countries. For instance, in the Scandinavian countries (Denmark, Norway, Sweden) and in Germany, over half the population provides an answer that does not diverge from the actual unemployment rate by more than 5 percentage points. Conversely, that share falls below a quarter of the respondents in Hungary, Latvia, Romenia or the United Kingdom.

Figure 2 confronts the actual and average perceived unemployment rates across countries, highlighting once again the tendency for the overestimation of the unemployment rate. Whereas any point along the diagonal line would mean that, on average, respondents in the country estimate correctly the unemployment rate, we find, instead, that all the dots lie far above the 45 degree line. Despite this general pattern, the striking differences across countries are confirmed. The Scandinavian countries, Finland and Germany present a low misperception of the unemployment rate; on the contrary, in Hungary, Romenia, Ireland, Slovenia, the United Kingdom, Ireland, France, and Belgium there is, on average, a large misperception of the unemployment rate.

One might have expected countries with low unemployment rate to have a low misperception of unemployment, if we quantify the misperception as the difference between the levels of perceived and actual rates. In this case, any gap of a given magnitude, suppose 1 percentage point, will mean a more serious mistake in a country with a low unemployment rate than in a country with a high one. Nevertheless, figure 2 shows that countries with the same unemployment rate can have widely different average levels of misperception of the unemployment rate - consider the examples of Sweden versus Great Britain or Estonia versus Hungary.

Therefore, in the empirical specification of the model we will as well consider the relative difference between the perceived and the actual unemployment rate, computed as:

$$
\text { ugap }_{\text {relative }}=\log \left(\frac{m[a, b]}{u}\right)=\log (m[a, b])-\log (u),
$$

where all variables keep their meaning from the previous equation.

Despite the fact that differences across countries in the average misperception of 
the unemployment rate may have an interest of their own, the analysis to be undertaken will exploit within-country variation in the misperception of unemployment to identify its impact on earnings, by including country fixed effects in all model specifications.

\section{What hides behind individuals' misperceptions of the unemployment rate?}

The perceived unemployment rate bears a connection to the actual unemployment rate, reflected in a correlation of 0.32 . Nevertheless, there is a sizable gap between the perception of unemployment and the actual rate, a curious fact that prompts two questions: What are the determinants of this gap? Will misperceptions of the labor market situation have implications on workers' outcomes? Whereas the latter is the core question driving this study, in this section we provide a brief discussion of certain correlates of the misperception of unemployment.

We are interested in checking whether the misperception of unemployment could be correlated with an individual's education level and with his ability. Moreover, we explore the idea that the regional unemployment rate might influence individual's perceptions of the national unemployment rate. Workers could be more aware of labor market conditions in their region of residence than in the country as a whole. If so, their reported perception of the national unemployment rate would track more closely the regional unemployment rate. As a result, our indicator of labor market information frictions would be larger, the larger the difference between the regional and the national unemployment rate.

Table 6 in Appendix B reports the results of a regression of the index of unemployment misperception as a function of our variables of interest, for the active population in the countries for which the regional unemployment rate is available. ${ }^{15}$

More educated workers provide a more accurate estimate of the country's unemployment rate (the misperception is reduced by 4 percentage points in case of upper secondary education and by 8 p.p. in the case of tertiary education, when compared to the omitted category of lower educational levels). More able workers (who understood the survey questions and did not need clarifications) also have

\footnotetext{
${ }^{15}$ The estimation sample includes both the employed and unemployed population, as it seems a more sensible sample on which to evaluate the determinants of unemployment misperceptions. Estimation on the analysis sample of employed workers yields coefficients with the same sign, similar magnitudes, but non-significant results on ability and the regional unemployment rate.
} 
more accurate perceptions of the unemployment rate. Unemployed workers perceive the unemployment rate to be larger than it actually is, consistent with the idea that own experience influences an individual's perception of the situation (with those who have had fewer job offers, such that they are unemployed, reporting a more pessimistic view of the labor market situation). Women report less accurately the unemployment rate than men, and older workers, in turn, report it more accurately.

The larger the regional unemployment rate, the larger an individual's misperception of the national unemployment rate (with a 0.3 percentage point larger misperception for each p.p. of the regional unemployment rate). Similarly, a larger difference between the regional and the national unemployment rates is associated with larger misperception of the national rate by the survey respondents. ${ }^{16}$

Altogether, in this exploratory analysis we find support for the relevance of introducing controls for workers' ability and for the regional unemployment rate in the regression aimed at estimating the impact of unemployment misperceptions on wages. Indeed, these variables are expected to influence the wage level and they are correlated with the unemployment misperception.

\section{$5 \quad$ Empirical strategy}

The estimation procedure takes into account the particular nature of the outcome variable (labor income), which was originally coded into country-specific bins, with known boundaries reported for each country by the ESS methodological documentation. Whenever the boundaries of the bins were defined in a currency other than Euro, we have converted them into Euro. We rely on interval regression and, in the robustness section, ordered probit, as two alternative estimation methods to model these interval data.

Let $Y_{i}$ stand for the $(\log )$ labor income of individual $i$, a continuous variable that is unobserved but is reported to fall on the interval $\left.] y_{1 i}, y_{2 i}\right]$; in the case of the last decile that by definition is right-censored, it falls on the interval $] y_{R i},+\infty[$; for the first decile, which is left-censored, it falls on the interval $\left[w, y_{L i}\right]$, with $w$ unknown. ${ }^{17}$

\footnotetext{
${ }^{16}$ We have also computed the gap between the perceived unemployment rate and the regional unemployment rate (instead of the national). We find that both gaps are highly correlated (coefficient above .98) and a formal test cannot reject the equality of their means.

${ }^{17}$ It will likely depend on the minimum wages enforced in the country, but the reported deciles may refer to yearly, monthly or weekly earnings, depending on the respondent's choice, which we do not know. Setting the lower bound of the interval in levels to zero similarly yields missing information on its logarithm. We therefore treat the first
} 
Consider the model:

$$
y_{i}=\boldsymbol{x}_{\boldsymbol{i}}^{\prime} \boldsymbol{\beta}+\epsilon_{i}
$$

where $y$ stands for $(\log )$ labor income, and $\boldsymbol{x}$ includes controls for the worker's gender, a quadratic term on age, education (two dummy variables), occupation (three dummies), as well as indicator variables for part-time work, whether the worker is a supervisor, holds an open-ended contract, and is unionized; the firm's size (two dummy variables) and industry (four dummies) are also controlled for. Additionally, demographic controls are included: whether the respondent lives with a partner and whether he has children below age 16 . The set of explanatory variables will be introduced sequentially. The key explanatory variable is the unemployment misperception, our indicator of misinformation on the labor market situation, computed as the gap between the perceived and the actual national unemployment rates. This gap is measured alternatively in levels or in logs, according to equations 3 and 4, respectively. $\epsilon_{i}$ is assumed to follow a Normal distribution with mean 0 and standard-deviation $\sigma$.

The likelihood contribution from worker $i$ whose earnings fall on interval $\left.] y_{1 i}, y_{2 i}\right]$ is $\operatorname{Pr}\left(y_{1 i}<Y_{i} \leq y_{2 i}\right)$; in the case of the right-censored interval it is $\operatorname{Pr}\left(Y_{i}>y_{R i}\right)$ and for the left-censored interval it is $\operatorname{Pr}\left(Y_{i} \leq y_{L i}\right)$. Therefore, the log-likelihood function defined over the unknown parameters $\boldsymbol{\beta}$ and $\sigma$ is given by:

$$
\begin{aligned}
\log L & =\sum_{i \in \operatorname{dec} I} \alpha_{i} \log \left\{\Phi\left(\frac{y_{2 i}-\boldsymbol{x}_{\boldsymbol{i}}^{\prime} \boldsymbol{\beta}}{\sigma}\right)-\Phi\left(\frac{y_{1 i}-\boldsymbol{x}_{\boldsymbol{i}}^{\prime} \boldsymbol{\beta}}{\sigma}\right)\right\} \\
& +\sum_{i \in \operatorname{dec} R} \alpha_{i} \log \left\{1-\Phi\left(\frac{y_{R i}-\boldsymbol{x}_{\boldsymbol{i}}^{\prime} \boldsymbol{\beta}}{\sigma}\right)\right\} \\
& +\sum_{i \in \operatorname{dec} L} \alpha_{i} \log \left\{\Phi\left(\frac{y_{L i}-\boldsymbol{x}_{\boldsymbol{i}}^{\prime} \boldsymbol{\beta}}{\sigma}\right)\right\}
\end{aligned}
$$

where decI refers to the interval data in deciles 2 to 9 , decR refers to the rightcensored data in decile 10 , and $d e c L$ refers to the left-censored data in the first decile. $\Phi$ is the cumulative standard normal distribution; $\alpha_{i}$ is the weight attached to observation $i$.

We are interested in the marginal impact of the independent variables - in particular, the unemployment misperception - on earnings, the latent variable. The estimated $\boldsymbol{\beta}$ vector directly quantifies the marginal effects of the independent varidecile as left-censored. 
ables on the latent outcome variable (for the specification and interpretation of the interval regression model, see Cameron and Trivedi, 2005: 529-542). A different situation wold occur if our variable of interest were the censored variable, in which case the marginal impacts would diverge from the estimated $\boldsymbol{\beta}$ vector. However, the variable of interest is the continuous variable, the one traditionally used in empirical models, which is reported by this particular data source in intervals that are not the object of economic interest.

As discussed in the previous sections, misperceptions of the unemployment rate could be correlated with the regional unemployment rate, the individual's unobserved ability or country-specific factors. The estimates of the impact of information frictions on wages would be biased by the omission of these variables. We follow three steps to tackle the problem.

First of all, we include the regional unemployment rate among the regressors, to capture the relationship between the regional unemployment rate and wages, widely documented as the wage curve. Blanchflower and Oswald (1994) report a consistent relationship between the regional unemployment rate and the regional wage level - an elasticity of -0.1 , with the estimates for a very large set of countries fluctuating around this value. By controlling for the regional unemployment rate, we aim, on one hand, at estimating the impact of information misperceptions on wages netting out the impact of the regional unemployment rate, thus correcting potential biases due to its omission. On the other hand, we aim at confronting our estimates of the impact of regional unemployment on wages with the benchmark estimated in the literature, to have an indication on the reliability of our overall empirical strategy. We rely on Eurostat (2014) for the regional unemployment rate, available on an yearly basis.

Secondly, we include country fixed effects among our regressors, which will capture any country-wide factors common to all individuals, such as labor market tightness, mobility costs or the institutional setting. Therefore, our identification of the impact of information frictions on wages comes from variation within country on misperceptions of the labor market situation.

Thirdly, we control for the worker ability by relying on the two proxy variables reported by the ESS interviewer when answering the questions: "Overall, did you feel that the respondent understood the questions?" (ESS, 2008c: 75); "Did the 
respondent ask for clarification on any questions?" (ESS, 2008c: 74). The answers were coded into five categories: never, almost never, now and then, often, or very often. We recoded each of these variables into a dummy variable: ability 1 equals one if the respondent understood the questions very often or often and zero otherwise; ability 2 equals one if the respondent never or almost never required clarifications on the questions and zero otherwise.

Tables 2 and 3 report the estimates of parameters $\boldsymbol{\beta}$ and $\sigma$ under different alternative model specifications. Several robustness checks are presented in Appendix B.

\section{The impact of information frictions on wages}

Table 2 reports the core results on interval estimation of the impact of information frictions on wages, relying on data for all countries in the analysis sample. However, for a few countries (Estonia, Finland, Ireland and Latvia), no data on regional unemployment rate were available. Therefore, table 3 replicates all estimations including the control for the regional unemployment rate, relying on the narrower set of countries for whom this variable is available. Throughout those tables, country fixed effects are included in the regressions. Columns 1 and 2 include controls for worker attributes (gender, a quadratic term on age and two education dummies). The two columns diverge because the second allows for the impact of unemployment misperceptions on wages to be different depending on whether the individual is pessimistic or optimistic about the current labor market situation. Column 3 further controls for the individual's ability, as proxied by the two variables reported by the survey interviewer on the respondent's understanding of the questions being asked. Column 4 augments the specification by including firm and job attributes (firm size, industry; the worker's broad occupation; whether the worker is a part-timer, performs a supervisor job, holds an open-ended contract, and is unionized). Finally, column 5 adds demographic controls (whether the worker lives with a partner and has any children). Whereas column (3) provides an indication on the impact of information frictions on wages, column (4) helps shed light on its mechanisms, as it controls for the attributes of the job the worker is matched to.

Note, first of all, that the coefficient estimates signs and magnitudes on the 
control variables fit what is widely known from traditional wage regressions. The gender wage penalty ranges from 15 to $24 \mathrm{log}$ points, depending on the set of control variables included in the model. The age earnings profile is concave, peaking around age 45 (results in column 4, which includes controls for job and firm attributes, as most often found in the literature). Tertiary education yields a large return over upper secondary education, in the order of 13 to $14 \log$ points (in column 4, see the difference between the return to tertiary and upper secondary education) (for an overview of the effect of educational levels on earnings, see Psacharopoulos (1994)). Introducing controls for the worker ability as proxied by its capacity to understand the survey questions (column 3), does not change the sign or magnitude of the coefficients previously estimated, while pointing to weak evidence of a wage premium for more able workers (ability2); nevertheless, the impact of ability becomes nonsignificant once we account for the job characteristics, firm characteristics and worker broad occupation. Larger firms pay higher wages. Part-time work is associated with lower wages, either because there is a penalty on hourly wages for part-time work or, by construction, when relying on earnings data (weekly, monthly or yearly) instead of hourly wages. The impact of trade union membership, though positive, is not significant, as would be expected in European countries, where extension of collective bargaining contracts to non-unionized workers is widespread. Workers performing supervisory tasks earn a wage premium of approximately $12 \%$; those on open-ended contracts earn a wage premium of $21 \%^{18}$. Married or cohabiting workers earn higher wages, consistent with the literature on the marital-status wage premium (Blackburn and Korenman, 1994). All of these estimates are very robust to the introduction of controls for the regional unemployment rate, in table 3. The consistency between the expected coefficients on the control variables and our results lends support to the procedure followed to infer the earnings data from the ESS dataset.

The impact of the regional unemployment rate on wages is also remarkably in line with the wisdom established by the previous literature (table 3). Indeed, our results point to an elasticity of wages with respect to the regional unemployment rate ranging from -.127 to -.096, whereas Blanchflower and Oswald (1994) derived the "law" of an elasticity of -.1.

The interesting addition to the wage and job search empirical literature concerns

\footnotetext{
${ }^{18}$ Either one computed as $\exp (\beta)-1$.
} 
our estimation of the impact of information frictions on wages (line 1 in either table 2 or 3$)$. We find that each percentage point misperception of the unemployment rate is associated with a wage decline of $0.7 \%$ (see the results in columns (1) to (3)) - a misperception of the labor market situation by 10 p.p. would thus result in a wage penalty of $7 \%$, which is a noteworthy impact, in particular if one keeps in mind that the average misperception is 13 p.p.. We further checked whether the impact could be different depending on whether the worker overshoots or undershoots when evaluating the country's unemployment rate. We would expect workers with a pessimistic view of the labor market to lower their reservation wages and thus earn lower wages; instead, workers with an optimistic view of the labor market could be over-confident and set too high reservation wages, though possibly having trouble finding a job. Consistent with that reasoning, we find that a pessimistic view of the labor market leads to lower wages. An optimistic view, instead, has no significant impact on wages (as indicated by a formal test on the sum of the estimated coefficients in lines 1 and 2 in each model specification), possibly due to the fact that very few of these workers underestimate the unemployment rate. Column (4) further introduces controls for job and employer attributes. Interestingly, the magnitude of the impact of information frictions on wages is reduced - each percentage point misperception of the unemployment rate is now associated with a wage decline of $0.4 \%$ - suggesting that part of the impact of misinformation on wages operates through worker matching to lower quality jobs.

\section{Robustness checks}

Robustness checks within the interval regression setting are presented in appendix, tables 7 and 8. We then consider a different estimation method altogether, reporting the results of the estimation of ordered probit models in tables 9 to 12 .

We depart from the regressions that included the control for the regional unemployment rate (table 3). First of all, we consider the relative gap in the perception of the unemployment rate, computed according to equation (4), instead of the absolute gap. We consistently find (see table 7 ) that workers who have a pessimistic view of the labor market opportunities earn lower wages, with an elasticity of wages with respect to the distance between perceived and actual unemployment rate of -.136 to 
-.092. Moreover, we still find that a optimistic view of labor market opportunities has no significant impact on wages (formal tests on the sum of the coefficients in the two first lines of each model). The regional unemployment elasticity of pay changes little, just like the estimated coefficients on all other control variables.

The following robustness check relies on an alternative weighting scheme, aimed at guaranteeing a uniform distribution of households in the original sample within each country across income deciles. Results are reported in table 8. Again, they are remarkably stable. ${ }^{19}$

We next perform a parallel analysis relying on ordered probit model estimation. The method is similar to the interval regression described above, except that the interval boundaries of the latent variable $Y_{i}$, here referred to as $\gamma_{j}$, are considered not known.

Consider the index function model of equation (5), where $y$ stands for the latent (log) labor income. The observed variable is $y_{i}=j$, where $j$ takes values from 1 to 10. If the individual labor income belongs to the first interval the observation is left-censored and we know that $Y_{i} \leq \gamma_{L}$; if it belongs to the last interval the observation is right-censored and therefore $Y_{i}>\gamma_{R}$; in every other case, we observe that $y_{i}=j$ if $\gamma_{1}<Y_{i} \leq \gamma_{2}$, where $\gamma_{1}$ and $\gamma_{2}$ are respectively the lower and the upper bound of the interval. We can then derive the probability that the (log) labor income $Y_{i}$ of the worker $i$ belongs to the category $j$, which is equal to:

$$
\begin{aligned}
\operatorname{Pr}\left[Y_{i}=j \mid \mathbf{x}_{i}\right] & =\operatorname{Pr}\left[\gamma_{1}<Y_{i} \leq \gamma_{2}\right]=\operatorname{Pr}\left[\gamma_{1}-\mathbf{x}_{i}^{\prime} \beta<\epsilon_{i} \leq \gamma_{2}-\mathbf{x}_{i}^{\prime} \beta\right] \\
& =F\left(\gamma_{2}-\mathbf{x}_{i}^{\prime} \beta\right)-F\left(\gamma_{1}-\mathbf{x}_{i}^{\prime} \beta\right)
\end{aligned}
$$

where $F$ is the cdf of $\epsilon$, which we assume follows a Normal distribution with mean 0 and variance $\sigma^{2}$. We maximize the following log-likelihood function in order to estimate the vectors of unknown parameters $\gamma$ and $\beta$ :

$$
\begin{aligned}
\log L & =\sum_{i \in \operatorname{dec} I} \alpha_{i} \log \left\{\Phi\left(\frac{\gamma_{2 i}-\boldsymbol{x}_{\boldsymbol{i}}^{\prime} \boldsymbol{\beta}}{\sigma}\right)-\Phi\left(\frac{\gamma_{1 i}-\boldsymbol{x}_{\boldsymbol{i}}^{\prime} \boldsymbol{\beta}}{\sigma}\right)\right\} \\
& +\sum_{i \in \operatorname{dec} R} \alpha_{i} \log \left\{1-\Phi\left(\frac{\gamma_{R i}-\boldsymbol{x}_{\boldsymbol{i}}^{\prime} \boldsymbol{\beta}}{\sigma}\right)\right\}
\end{aligned}
$$

\footnotetext{
${ }^{19}$ We also clustered the standard errors at the region level within each country, to account for the possibility that misperceptions of the unemployment rate are correlated within a region. The significance level of all estimated coefficients does not change, with the exception of that on the regional unemployment rate, whose coefficient becomes non-significant, pointing once again to the robustness of the major results. These results are available from the authors upon request.
} 


$$
+\sum_{i \in \operatorname{dec} L} \alpha_{i} \log \left\{\Phi\left(\frac{\gamma_{L i}-\boldsymbol{x}_{\boldsymbol{i}}^{\prime} \boldsymbol{\beta}}{\sigma}\right)\right\},
$$

where all variables keep their previous meaning, with $\gamma$ referring to the interval boundaries of the latent variable. However, we should recall that these estimates by themselves are of limited interest. Indeed, consider the marginal effect of a change in $x_{i}$ on the $\operatorname{Pr}\left[y_{i}=j \mid x_{i}\right]$ :

$$
\frac{\partial \operatorname{Pr}\left[y_{i}=j \mid x_{i}\right]}{\partial x}=\left[F^{\prime}\left(\gamma_{j-1}-\mathbf{x}^{\prime} \beta\right)-F^{\prime}\left(\gamma_{j}-\mathbf{x}^{\prime} \beta\right)\right] \beta
$$

where $F^{\prime}$ denotes the derivative of $F$. The term in brackets can be either positive or negative and it does not equal 1 , hence the estimated coefficients in $\beta$ cannot be directly interpreted. From the likelihood function it can be noticed that, unlike in the interval regression case, in the ordered probit (or probit) model, $\sigma$ and the other parameters cannot be separately identified and therefore we cannot interpret $\beta$ as marginal effect on the latent variable. Tables 9 and 10 in appendix report the estimated $\beta$, following specifications parallel to tables 2 and $3 .^{20}$

Tables 11 and 12 report the estimates of the marginal effect of the unemployment misperception on the probability that worker $i$ 's earnings fall on a given interval, holding all the other variables at their average values. Results are in line with those on interval regression. In general, an increase in the unemployment misperception increases the probability that the labor income belongs to the four lowest brackets; conversely, it decreases the probability that the worker's earnings belong to the remaining six upper brackets. To have a concrete example, consider specification 5 of table 11: a 10 percentage point increase of unemployment misperception can be translated into a $5 \%$ increase in the probability of belonging to the bottom part of the distribution (first four categories) and a $5 \%$ decrease of the probability of belonging to the remaining six categories. Comparable patterns can be observed analyzing table 12 . Results of the estimation of the ordered probit therefore confirm those on interval regression.

\section{A potential mechanism? Misperceptions of the labor market situation and worker's career decisions}

A gap between the country's unemployment rate perceived by a worker and the actual unemployment rate provides a measure of misunderstanding of the degree of

\footnotetext{
${ }^{20}$ The estimates of the intervals' boundaries $\gamma$ are not reported.
} 
labor market tightness by the worker. This misperception is bound to affect individual behavior in the labor market - to the extent that a pessimistic view is associated with concern over becoming unemployed, it is expected to influence decisions such as that on the reservation wage. Whereas there is no data available that would enable a full test of this hypothesis, we can nevertheless explore whether the misperception of the unemployment rate is associated with an individual's expectation of becoming unemployed. Such evidence would provide a possible channel for the misperceptions on the situation of the labor market to impact wages.

Participants in the survey were asked "how likely it is that during the next 12 months you will be unemployed and looking for work for at least four consecutive weeks? (ESS, 2008c: 35). The possible answers were: very likely, likely, not likely, not at all likely. We generate a dummy variable that takes value one if the answer was "very likely" or "likely" and zero otherwise. We estimate the probability of a positive answer as a function of the unemployment misperception and a set of covariates, controlling for country fixed effects. The covariates include the actual unemployment rate in the country (which varies depending on the survey month), the worker's age, gender, education, and ability, as well as her current labor market status (dummy for unemployed, with employed as the omitted category; and a dummy with value one if the individual is employed on a permanent contract and zero otherwise). This set of regressors replicates those in our major specification of the wage model, in column (3) of table 2, augmented to include the job attribute that is expected to have a direct impact on perceptions of future unemployment, namely the duration of the current employment contract (open-ended, as opposed to short duration). The regressions were run both on the sample of active population (in which case we further control for the current unemployment status) and on the analysis sample, which includes only employed workers. Results are reported in table 4 .

For the active population, the covariates that describe the working status have signs aligned with expectations. Being unemployed increases the most the perceived likelihood of future unemployment. Having a permanent contract points in the opposite direction, even though the absolute magnitude of the effect is smaller. More educated individuals show less concern over the possibility of being unemployed. No significant gender differences are detected. 
The coefficient of the unemployment misperception is significant and positive - the overestimation of the unemployment rate is associated with a higher perceived probability of being unemployed in the near future. Conversely, the underestimation of the country's unemployment rate is associated with a lower perceived probability of being unemployed in the near future (though significant only at the $10 \%$ level).

For the working population, those on an open-ended contract are less likely to believe they will be unemployed in the near future. Just like for the active population as a whole, we find that the overestimation of the unemployment rate is associated with a higher perceived probability of being unemployed in the near future. For those who underestimate the unemployment rate, in turn, we cannot reject the hypothesis that such misperception has no impact on their perceived likelihood of being unemployed in the next 12 months $^{21}$.

These results suggest that the misperception of a national phenomenon - the country unemployment rate - is associated with expectations about own labor market prospects. Therefore, the information gap is likely to affect labor market choices, in particular the definition of the wage threshold for a job offer to be deemed acceptable.

This finding provides a potential mechanism for the impact of information frictions on the wage level, in line with the predictions of job search and matching theory. According to Diamond (1982), the matching process in the labor market yields multiple equilibria that are rankable according to the aggregate welfare of the two sides. The equilibria depend on the rational expectation that employers have about the future: if the employers are optimistic, more job-vacancies are created and the unemployment rate decreases; in the pessimistic case, the number of job vacancies is low and unemployment is high. Similarly, we can think of the argument from a worker's perspective: if workers are pessimistic about the job opportunities the labor market has to offer (e.g. they overestimate the unemployment rate), their expectations about their employment chances in the near future and wages are lower. Employers could exploit this information friction, having more bargaining power that would allow them to offer lower wages.

\footnotetext{
${ }^{21}$ The coefficient on the negative misperception (line 2) is very imprecisely estimated. Therefore, we cannot reject the hypothesis that the impact of the under-estimation of the unemployment rate is zero (sum of the coefficients in lines 1 and 2), just like we cannot reject that it is equal to the impact of over-estimation of the unemployment rate.
} 


\section{Conclusion}

We contribute to the empirical literature on the impact of labor market frictions on wages by proposing a direct measure of workers' information frictions - their misperceptions of the labor market tightness in the country, evaluated as the gap between the perceived unemployment rate and the country's actual unemployment rate. We estimate wage regressions including worker attributes, as well as firm and job attributes, augmented to include our key variable of interest, the degree of misperception by the worker of the labor market situation. To account for the interval nature of the outcome variable, we estimate both interval regression and ordered probit models. We adopt a threefold strategy to tackle potential endogeneity problems: controlling for worker ability; including country fixed effects; controlling for the unemployment rate in the region of residence.

We find that workers' pessimistic view of the labor market situation lowers their wages - each 1 percentage point deviation of the perceived unemployment rate from the actual one translates into a reduction in wages of $0.7 \%$ ( $4 \%$ once we control for job and employer attributes). This result is very robust to alternative specifications of the model. In turn, an optimistic view of the labor market has no significant impact on wages. We discuss a possible mechanisms driving these result. An overestimation of the unemployment rate leads to concern over own future employment prospects and is therefore likely to lower reservation wages; its underestimation, on the contrary, could raise reservation wages, but it would render job finding more difficult.

The fact that the estimates of the coefficients on the other variables included in the model fit remarkably well the expectations drawn from the profusion of literature on wage regressions in general and the regional wage curve in particular, points to the reliability of the procedure followed to infer earnings data from the ESS data.

\section{References}

Albrecht, James W. and Bo Axell (1984) "An Equilibrium Model of Search Unemployment." Journal of Political Economy, 92(5): 824-840.

Baye, Michael R., John Morgan, and Patrick Scholten (2006). Information, Search, 
and Price Dispersion. In T. Hendershott (ed.) Handbook on Economics and Information Systems. Amsterdam: Elsevier, p. 323-375.

Blackburn, McKinley and Sanders Korenman (1994). "The Declining Maritalstatus Earnings Differential." Journal of Population Economics, 7(3): 247-270.

Blanchflower, David G. and Andrew J. Oswald (1994). The Wage Curve. Cambridge, MA: MIT Press.

Burdett, Kenneth and Kenneth L. Judd (1983). "Equilibrium Price Dispersion." Econometrica, 51(4): 955-969.

Burdett, Kenneth and Dale T. Mortensen (1998). "Wage Differentials, Employer Size, and Unemployment." International Economic Review, 39(2): 257-273.

Cahuc, Pierre, Stphane Carcillo and Andr Zylberberg (2014). Labor Economics, second edition. Cambridge MA: MIT Press.

Cameron and Trivedi (2005). Microeconometrics: Methods and Applications, second edition. Cambridge: Cambridge University Press.

Diamond, Peter A. (1971). "A Model of Price Adjustment." Journal of Economic Theory, 3: 156-168.

Diamond, Peter A. (1982). "Wage Determination and Efficiency in Search Equilibrium." Review of Economic Studies, 49(2): 217-27.

European Social Survey Round 4 Data (2008). Data file edition 4.3. Norwegian Social Science Data Services, Norway - Data Archive and distributor of ESS data.

European Social Survey (2008a). European Social Survey 2008 Data Protocol, Edition 1.2. Bergen, European Social Survey Data Archive, Norwegian Social Science Data Services.

European Social Survey (2008b). European Social Survey 2008 Project Instructions. Bergen, European Social Survey Data Archive, Norwegian Social Science Data Services. 
European Social Survey (2008c). European Social Survey 2008 Source Questionnaire Amendment 03 (Round 4, 2008/9). Bergen, European Social Survey Data Archive, Norwegian Social Science Data Services.

European Social Survey (2008d). European Social Survey 2008, Appendix A5, Income, ed. 5.0. Bergen, European Social Survey Data Archive, Norwegian Social Science Data Services.

European Social Survey (2010). ESS-4 2008 Documentation Report. Edition 5.1. Bergen, European Social Survey Data Archive, Norwegian Social Science Data Services.

European Social Survey (2014). Weighting European Social Survey. Bergen, European Social Survey Data Archive, Norwegian Social Science Data Services.

Eurostat (2014). "Unemployment rate by NUTS 2 regions."

http://ec.europa.eu/eurostat/web/products-datasets/-/tgs00010, accessed June.

Eurostat (2013). "Harmonised unemployment rates (\%) - monthly data."

http://ec.europa.eu/eurostat/web/products-datasets/-/ei_lmhr_m , accessed August.

Galí (2011). "The Return of the Phillips Curve." Journal of the European Economic Association, 9(3): 436-461.

Groves, Robert M., Floyd J. Fowler, Jr., Mick P. Couper, James M. Lepkowski, Eleanor Singer, and Roger Tourangeau (2009). Survey Methodology, 2nd edition. New Jersey: John Wiley.

Hoffmeyer-Zlotnik, Jrgen H.P. and Uwe Warner (2006). "Methodological Discussion of the Income Measure in the European Social Survey Round 1." Metodoloski Zvezki - Advances in Methodology and Statistics, 3(2): 289-334.

Ipsos MORI (2014) "Perceptions Are not Reality: Things the World Gets Wrong." Website https://www.ipsos-mori.com/researchpublications/researcharchive/3466/Perceptionsare-not-reality-10-things-the-world-gets-wrong.aspx , accessed May 13, 2015.

Jensen, Robert (2007). "The Digital Provide: Information (Technology), Market Performance, and Welfare in the South Indian Fisheries Sector." Quarterly Journal of Economics, 122(3): 879-924. 
Kalton, Graham (1983). Compensating for Missing Survey Data. Ann Arbor, Michigan: Survey Research Center Institute for Social Research, University of Michigan.

Ljungqvist, Lars and Thomas J. Sargent (2004). Recursive Macroeconomic Theory, second edition. Cambridge MA: MIT Press.

Micklewright, John and Sylke V. Schnepf (2010). "How Reliable Are Income Data Collected with a Single Question?" Journal of the Royal Statistical Society: Series A, 173(2): 409-429.

Moore, Ramon E., R. Baker Kearfott and Michael J. Cloud (2009). Introduction to Interval Analysis. Philadelphia: Society for Industrial and Applied Mathematics.

Mortensen, Dale T. (1999). New Developments in Models of Search in the Labor Market. In O. Ashenfelter and D. Card (eds.) Handbook of Labor Economics. Amsterdam: Elsevier, p. 2567-2627.

Petrongolo, Barbara and Christopher A. Pissarides (2001). "Looking into the Black Box: A Survey of the Matching Function." Journal of Economic Literature, 39(2): 390-431.

Pissarides, Christopher A. (2011). "Equilibrium in the Labor Market with Search Frictions." American Economic Review, 101: 1092-1105.

Postel-Vinay, Fabien and Jean-Marc Robin (2002). "Equilibrium Wage Dispersion with Worker and Employer Heterogeneity." Econometrica, 70(6): 2295-2350.

Psacharopoulos, George (1994). "Returns to Investment in Education: A Global Update." World Development, 22(9): 1325-1343.

Stigler, George J. (1962). "Information in the Labor Market." Journal of Political Economy, 70(5): 94-105.

van den Berg, Gerard J. and Geert Ridder (1998). "An Empirical Equilibrium Search Model of the Labor Market." Econometrica, 66(5): 1183-1221.

van den Berg, Gerard J. and Aico van Vuuren (2010). "The Effect of Search Frictions on Wages." Labour Economics, 17: 875-885. 


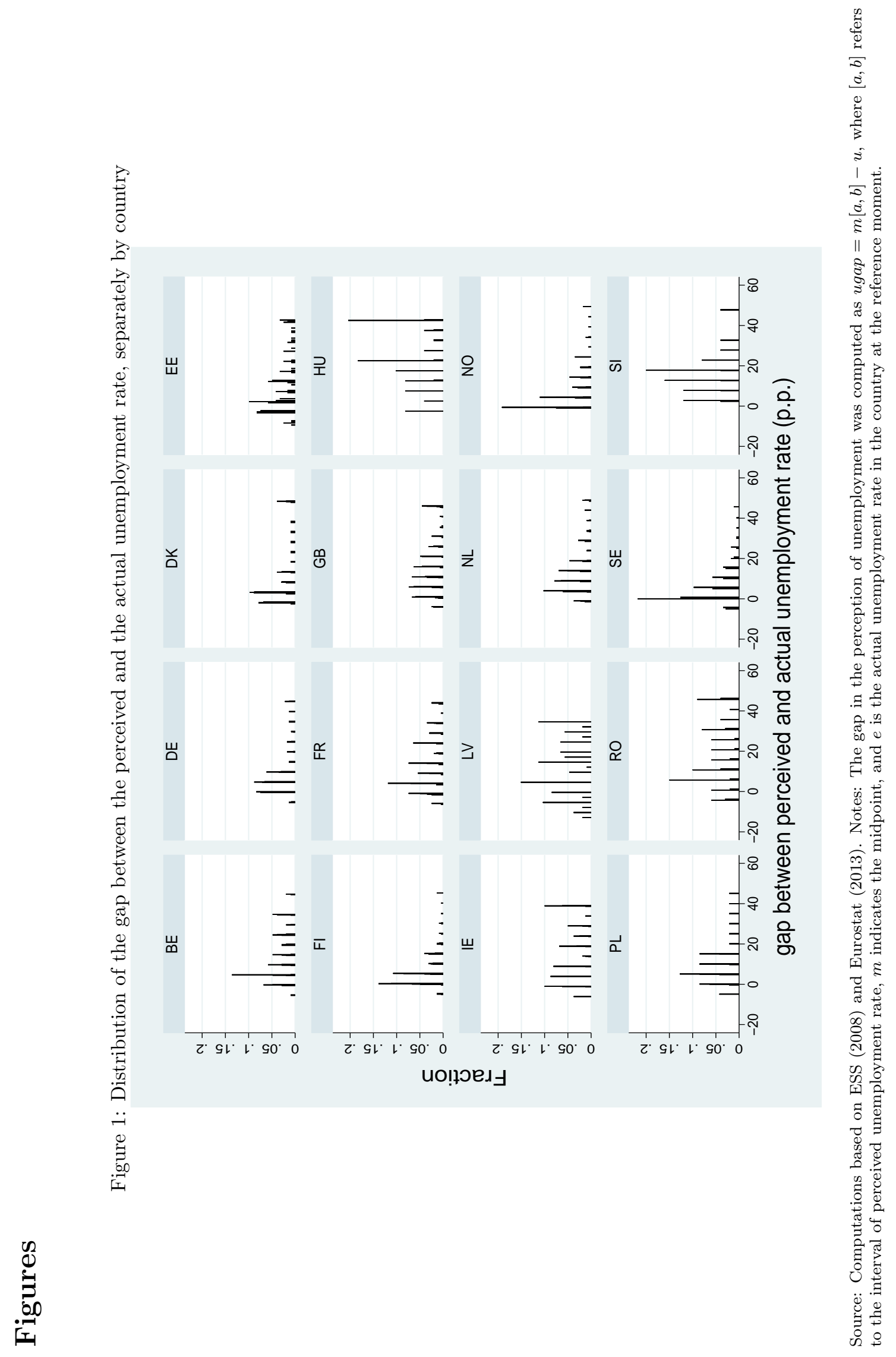




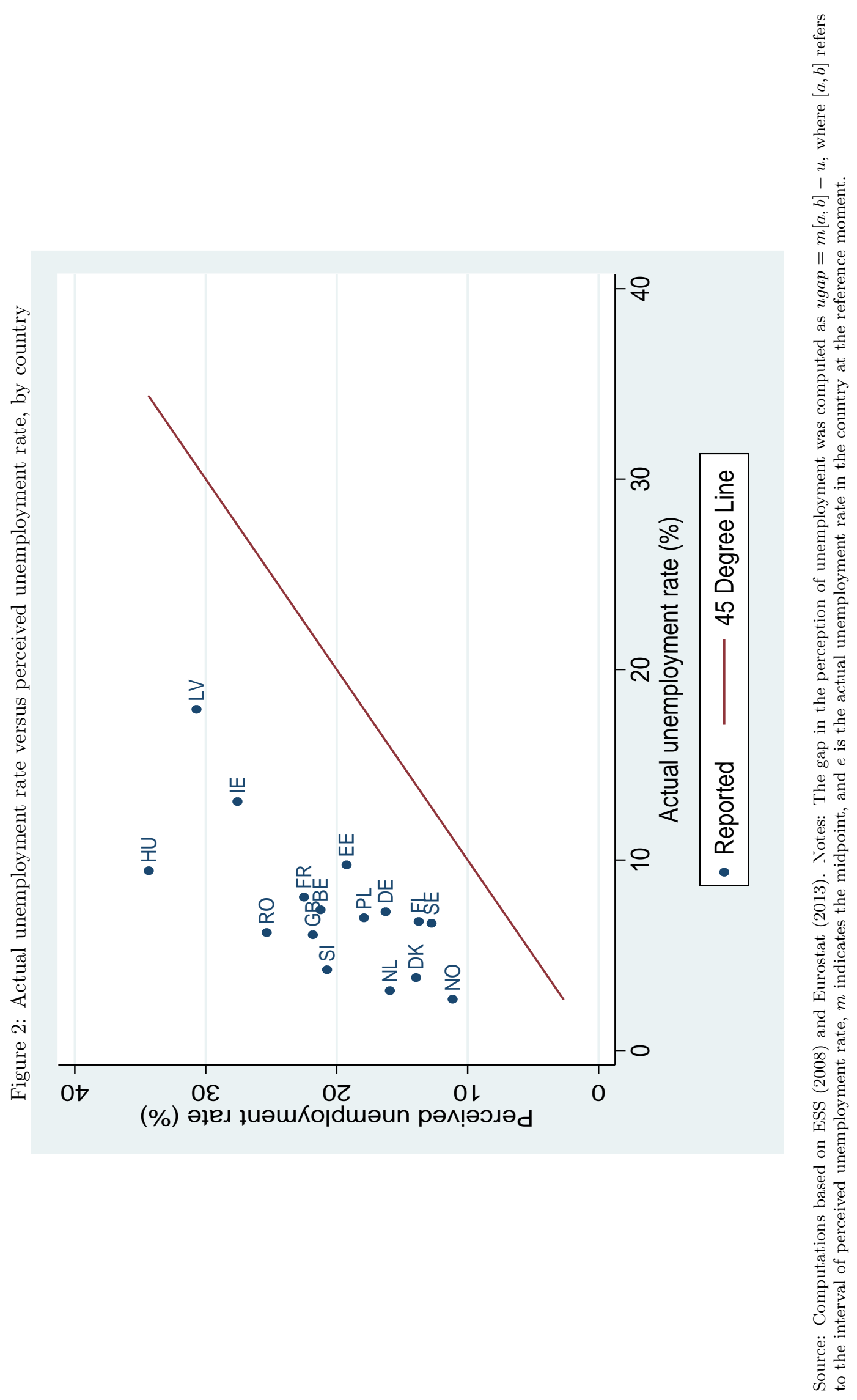




\section{Tables}

Table 1: Descriptive statistics, analysis sample

\begin{tabular}{|c|c|c|}
\hline variable & mean or share & st. dev. \\
\hline (Log) earnings, lower bound of decile (euro) & 7.353 & 0.659 \\
\hline ( $\mathrm{Log}$ ) earnings, upper bound of decile (euro) & 7.456 & 0.648 \\
\hline Misperception unemployment, p.p. (abs value) & 12.814 & 13.08 \\
\hline if misperception positive & 15.445 & 13.179 \\
\hline if misperception negative & 1.568 & 1.957 \\
\hline share with negative misperception & 0.190 & \\
\hline (Log) regional unemployment rate & 1.803 & 0.378 \\
\hline Female & 0.405 & \\
\hline Age & 40.12 & 11.14 \\
\hline \multicolumn{3}{|l|}{ Education (less than upper secondary omitted) } \\
\hline upper secondary & 0.425 & \\
\hline tertiary & 0.400 & \\
\hline Ability1 & 0.956 & \\
\hline Ability2 & 0.774 & \\
\hline \multicolumn{3}{|l|}{ Firm size (1-99 omitted) } \\
\hline $100-500$ & 0.230 & \\
\hline $500+$ & 0.184 & \\
\hline \multicolumn{3}{|l|}{ Industry (other services omitted) } \\
\hline primary sector & 0.013 & \\
\hline manufacturing & 0.203 & \\
\hline construction & 0.073 & \\
\hline finance & 0.045 & \\
\hline \multicolumn{3}{|l|}{ Occupation (unskilled omitted) } \\
\hline clerks, serv., sales & 0.240 & \\
\hline skilled, machine opers & 0.204 & \\
\hline managers, profls., technicians & 0.459 & \\
\hline Part-timer & 0.102 & \\
\hline Supervisor & 0.365 & \\
\hline Open end contract & 0.828 & \\
\hline Trade union member & 0.264 & \\
\hline Children below 16 (yes/no) & 0.257 & \\
\hline Partner (yes/no) & 0.167 & \\
\hline Number Obs. $(*)$ & 2,310 & \\
\hline
\end{tabular}

Source: Computations based on ESS (2008). Notes: The misperception index is computed according to equation 3 (i.e. the difference between the perceived and the actual unemployment rate in the country); ability 1 equals one if the respondent understood the questions very often or often and zero otherwise; ability2 equals one if the respondent never or almost never required clarifications on the questions and zero otherwise. Uses ESS post-stratification weights combined with population size weights. $\left(^{*}\right) 88$ observations on earnings are left-censored and 89 are right-censored; data is missing for 11, 7, and 37 observations, on ability1, ability 2 , and part-timer, respectively. For the regional unemployment rate, the number of observations is 1,700, as data are not available for four countries (see text). 
Table 2: Interval regression, (log) wages on level of misperception of unemployment

\begin{tabular}{|c|c|c|c|c|c|}
\hline & $(1)$ & $(2)$ & $(3)$ & $(4)$ & $(5)$ \\
\hline misperception unemployment (abs value) & $\begin{array}{c}-.007^{* * *} \\
(.001)\end{array}$ & $\begin{array}{c}-.007^{* * *} \\
(.001)\end{array}$ & $\begin{array}{c}-.007^{* * *} \\
(.001)\end{array}$ & $\begin{array}{c}-.004^{* * *} \\
(.001)\end{array}$ & $\begin{array}{c}-.004^{* * *} \\
(.001)\end{array}$ \\
\hline misperc. unempl. if neg. (abs value) & & $\begin{array}{l}.010 \\
(.010)\end{array}$ & $\begin{array}{l}.011 \\
(.010)\end{array}$ & $\begin{array}{l}.002 \\
(.010)\end{array}$ & $\begin{array}{l}.002 \\
(.011)\end{array}$ \\
\hline female & $\begin{array}{c}-.237^{* * *} \\
(.029)\end{array}$ & $\begin{array}{c}-.236^{* * *} \\
(.029)\end{array}$ & $\begin{array}{c}-.235^{* * *} \\
(.029)\end{array}$ & $\begin{array}{c}-.187^{* * *} \\
(.030)\end{array}$ & $\begin{array}{c}-.147^{* * *} \\
(.031)\end{array}$ \\
\hline age & $\begin{array}{c}.025^{* * *} \\
(.008)\end{array}$ & $\begin{array}{c}.025^{* * *} \\
(.008)\end{array}$ & $\begin{array}{c}.025^{* * *} \\
(.008)\end{array}$ & $\begin{array}{l}.019^{* *} \\
(.007)\end{array}$ & $\begin{array}{c}.012 \\
(.008)\end{array}$ \\
\hline age sq. & $\begin{array}{c}-.0002^{* *} \\
(.0001)\end{array}$ & $\begin{array}{c}-.0002^{* *} \\
(.0001)\end{array}$ & $\begin{array}{c}-.0002^{* *} \\
(.0001)\end{array}$ & $\begin{array}{c}-.0002^{* *} \\
(.00009)\end{array}$ & $\begin{array}{l}-.0001 \\
(.00009)\end{array}$ \\
\hline educ. upper second. & $\begin{array}{c}.150^{* * *} \\
(.043)\end{array}$ & $\begin{array}{c}.151^{* * *} \\
(.043)\end{array}$ & $\begin{array}{c}.143^{* * *} \\
(.043)\end{array}$ & $\begin{array}{l}.045 \\
(.038)\end{array}$ & $\begin{array}{l}.051 \\
(.038)\end{array}$ \\
\hline educ. tertiary & $\begin{array}{l}.423^{* * *} \\
(.044)\end{array}$ & $\begin{array}{l}.423^{* * *} \\
(.044)\end{array}$ & $\begin{array}{c}.412^{* * *} \\
(.044)\end{array}$ & $\begin{array}{c}.180^{* * *} \\
(.044)\end{array}$ & $\begin{array}{c}.179^{* * *} \\
(.044)\end{array}$ \\
\hline ability1 & & & $\begin{array}{l}-.012 \\
(.084)\end{array}$ & $\begin{array}{l}-.066 \\
(.081)\end{array}$ & $\begin{array}{l}-.082 \\
(.085)\end{array}$ \\
\hline ability 2 & & & $\begin{array}{l}.059^{*} \\
(.031)\end{array}$ & $\begin{array}{l}-.002 \\
(.028)\end{array}$ & $\begin{array}{l}.009 \\
(.028)\end{array}$ \\
\hline firm size $100-500$ & & & & $\begin{array}{c}.070^{* *} \\
(.030)\end{array}$ & $\begin{array}{c}.059^{* *} \\
(.029)\end{array}$ \\
\hline firm size $500+$ & & & & $\begin{array}{c}.126^{* * *} \\
(.038)\end{array}$ & $\begin{array}{c}.129^{* * *} \\
(.037)\end{array}$ \\
\hline part-timer & & & & $\begin{array}{c}-.172^{* * *} \\
(.049)\end{array}$ & $\begin{array}{c}-.184^{* * *} \\
(.047)\end{array}$ \\
\hline trade union member & & & & $\begin{array}{l}.006 \\
(.029)\end{array}$ & $\begin{array}{l}.013 \\
(.029)\end{array}$ \\
\hline supervisor & & & & $\begin{array}{c}.117^{* * *} \\
(.028)\end{array}$ & $\begin{array}{c}.111^{* * *} \\
(.027)\end{array}$ \\
\hline open end contract & & & & $\begin{array}{c}.186^{* * *} \\
(.034)\end{array}$ & $\begin{array}{c}.167^{* * *} \\
(.034)\end{array}$ \\
\hline children below 16 (yes/no) & & & & & $\begin{array}{l}.039 \\
(.030)\end{array}$ \\
\hline partner & & & & & $\begin{array}{c}.184^{* * *} \\
(.039)\end{array}$ \\
\hline Const. & $\begin{array}{c}6.743^{* * *} \\
(.175)\end{array}$ & $\begin{array}{c}6.738^{* * *} \\
(.174)\end{array}$ & $\begin{array}{c}6.700^{* * *} \\
(.191)\end{array}$ & $\begin{array}{c}6.630^{* * *} \\
(.174)\end{array}$ & $\begin{array}{c}6.726^{* * *} \\
(.172)\end{array}$ \\
\hline \multicolumn{6}{|l|}{ Controls for: } \\
\hline country fixed effects & yes & yes & yes & yes & yes \\
\hline industry (4 dummies) & no & no & no & yes & yes \\
\hline occupation (3 dummies) & no & no & no & yes & yes \\
\hline Obs. & 2310 & 2310 & 2299 & 2263 & 2263 \\
\hline $\log -L$ & -3614.4 & -3613.9 & -3607.2 & -3365.7 & -3332.3 \\
\hline$\sigma$ & .410 & .410 & .409 & .364 & 357 \\
\hline
\end{tabular}

Source: Computations based on ESS (2008). Notes: The misperception index is computed according to equation 3 (i.e. the difference between the perceived and the actual unemployment rate in the country); its absolute value is the regressor in line 1 ; in line 2 , the absolute value of the misperception index is interacted with a dummy variable equal to one if the misperception is negative and zero otherwise. Uses ESS post-stratification weights combined with population size weights. Robust standard-errors in parenthesis. 
Table 3: Interval regression, (log) wages on level of misperception of unemployment; including control for the regional unemployment rate

\begin{tabular}{|c|c|c|c|c|c|}
\hline & $(1)$ & $(2)$ & $(3)$ & $(4)$ & $(5)$ \\
\hline misperception unemployment (abs value) & $\begin{array}{c}-.007^{* * *} \\
(.001)\end{array}$ & $\begin{array}{c}-.007^{* * *} \\
(.001)\end{array}$ & $\begin{array}{c}-.007^{* * *} \\
(.001)\end{array}$ & $\begin{array}{c}-.004^{* * *} \\
(.001)\end{array}$ & $\begin{array}{c}-.004^{* * *} \\
(.001)\end{array}$ \\
\hline misperc. unempl. if neg. (abs value) & & $\begin{array}{l}.011 \\
(.011)\end{array}$ & $\begin{array}{c}.011 \\
(.011)\end{array}$ & $\begin{array}{l}.002 \\
(.011)\end{array}$ & $\begin{array}{l}.001 \\
(.012)\end{array}$ \\
\hline (log) regional unempl. rate & $\begin{array}{c}-.126^{* *} \\
(.051)\end{array}$ & $\begin{array}{c}-.126^{* *} \\
(.051)\end{array}$ & $\begin{array}{c}-.127^{* *} \\
(.051)\end{array}$ & $\begin{array}{c}-.101^{* *} \\
(.044)\end{array}$ & $\begin{array}{c}-.096^{* *} \\
(.042)\end{array}$ \\
\hline female & $\begin{array}{c}-.239^{* * *} \\
(.030)\end{array}$ & $\begin{array}{c}-.238^{* * *} \\
(.030)\end{array}$ & $\begin{array}{c}-.236^{* * *} \\
(.030)\end{array}$ & $\begin{array}{c}-.188^{* * *} \\
(.031)\end{array}$ & $\begin{array}{c}-.150^{* * *} \\
(.032)\end{array}$ \\
\hline age & $\begin{array}{c}.025^{* * *} \\
(.009)\end{array}$ & $\begin{array}{c}.025^{* * *} \\
(.009)\end{array}$ & $\begin{array}{c}.026^{* * *} \\
(.009)\end{array}$ & $\begin{array}{c}.019^{* *} \\
(.008)\end{array}$ & $\begin{array}{l}.012 \\
(.008)\end{array}$ \\
\hline age sq. & $\begin{array}{c}-.0002^{* *} \\
(.0001)\end{array}$ & $\begin{array}{c}-.0002^{* *} \\
(.0001)\end{array}$ & $\begin{array}{c}-.0002^{* *} \\
(.0001)\end{array}$ & $\begin{array}{l}-.0002^{*} \\
(.00009)\end{array}$ & $\begin{array}{l}-.0001 \\
(.0001)\end{array}$ \\
\hline educ. upper second. & $\begin{array}{c}.156^{* * *} \\
(.046)\end{array}$ & $\begin{array}{c}.158^{* * *} \\
(.046)\end{array}$ & $\begin{array}{c}.151^{* * *} \\
(.046)\end{array}$ & $\begin{array}{l}.049 \\
(.040)\end{array}$ & $\begin{array}{l}.053 \\
(.040)\end{array}$ \\
\hline educ. tertiary & $\begin{array}{c}.429^{* * *} \\
(.046)\end{array}$ & $\begin{array}{c}.429^{* * *} \\
(.046)\end{array}$ & $\begin{array}{c}.419^{* * *} \\
(.046)\end{array}$ & $\begin{array}{c}.184^{* * *} \\
(.046)\end{array}$ & $\begin{array}{c}.183^{* * *} \\
(.046)\end{array}$ \\
\hline ability1 & & & $\begin{array}{l}-.024 \\
(.089)\end{array}$ & $\begin{array}{l}-.076 \\
(.085)\end{array}$ & $\begin{array}{l}-.093 \\
(.088)\end{array}$ \\
\hline ability 2 & & & $\begin{array}{l}.059^{*} \\
(.032)\end{array}$ & $\begin{array}{l}-.002 \\
(.029)\end{array}$ & $\begin{array}{l}.009 \\
(.029)\end{array}$ \\
\hline firm size $100-500$ & & & & $\begin{array}{l}.070^{* *} \\
(.032)\end{array}$ & $\begin{array}{l}.058^{*} \\
(.031)\end{array}$ \\
\hline firm size $500+$ & & & & $\begin{array}{c}.125^{* * *} \\
(.039)\end{array}$ & $\begin{array}{c}.127^{* * *} \\
(.038)\end{array}$ \\
\hline part-timer & & & & $\begin{array}{c}-.174^{* * *} \\
(.052)\end{array}$ & $\begin{array}{c}-.187^{* * *} \\
(.049)\end{array}$ \\
\hline trade union member & & & & $\begin{array}{l}-.003 \\
(.031)\end{array}$ & $\begin{array}{l}.003 \\
(.031)\end{array}$ \\
\hline supervisor & & & & $\begin{array}{c}.112^{* * *} \\
(.029)\end{array}$ & $\begin{array}{c}.107^{* * *} \\
(.028)\end{array}$ \\
\hline open end contract & & & & $\begin{array}{c}.192^{* * *} \\
(.036)\end{array}$ & $\begin{array}{c}.173^{* * *} \\
(.036)\end{array}$ \\
\hline children below 16 (yes/no) & & & & & $\begin{array}{l}.044 \\
(.032)\end{array}$ \\
\hline partner & & & & & $\begin{array}{c}.181^{* * *} \\
(.041)\end{array}$ \\
\hline Const. & $\begin{array}{c}6.982^{* * *} \\
(.213)\end{array}$ & $\begin{array}{c}6.977^{* * *} \\
(.212)\end{array}$ & $\begin{array}{c}6.951^{* * *} \\
(.224)\end{array}$ & $\begin{array}{c}6.824^{* * *} \\
(.205)\end{array}$ & $\begin{array}{c}6.913^{* * *} \\
(.202)\end{array}$ \\
\hline \multicolumn{6}{|l|}{ Controls for: } \\
\hline country fixed effects & yes & yes & yes & yes & yes \\
\hline industry (4 dummies) & no & no & no & yes & yes \\
\hline occupation (3 dummies) & no & no & no & yes & yes \\
\hline Obs. & 1700 & 1700 & 1695 & 1673 & 1673 \\
\hline $\log -L$ & -3446.9 & -3446.3 & -3441.0 & -3208.8 & -3176.9 \\
\hline$\sigma$ & .410 & .410 & .409 & .364 & .357 \\
\hline
\end{tabular}

Source: Computations based on ESS (2008). Notes: The misperception index is computed according to equation 3 (i.e. the difference between the perceived and the actual unemployment rate in the country); its absolute value is the regressor in line 1 ; in line 2 , the absolute value of the misperception index is interacted with a dummy variable equal to one if the misperception is negative and zero otherwise. Uses ESS post-stratification weights combined with population size weights. Robust standard-errors in parenthesis. 
Table 4: Perceived probability of being unemployed within the next 12 months, probit model

\begin{tabular}{|c|c|c|c|c|}
\hline & \multicolumn{2}{|c|}{ all active population } & \multicolumn{2}{|c|}{ analysis sample } \\
\hline & coef. & marg. impact & coef. & marg. impact \\
\hline misperception unemployment (abs value) & $\begin{array}{l}.007^{* * *} \\
(.002)\end{array}$ & $\begin{array}{c}.002^{* * *} \\
(.000)\end{array}$ & $\begin{array}{l}.011^{* * *} \\
(.004)\end{array}$ & $\begin{array}{c}.003^{* * *} \\
(.001)\end{array}$ \\
\hline misperc. unempl. if neg. (abs value) & $\begin{array}{c}-.040^{* *} \\
(.020)\end{array}$ & $\begin{array}{c}-.011^{* *} \\
(.006)\end{array}$ & $\begin{array}{l}-.024 \\
(.048)\end{array}$ & $\begin{array}{l}-.006 \\
(.012)\end{array}$ \\
\hline female & $\begin{array}{l}-.003 \\
(.042)\end{array}$ & $\begin{array}{l}-.001 \\
(.012)\end{array}$ & $\begin{array}{l}-.089 \\
(.110)\end{array}$ & $\begin{array}{l}-.022 \\
(.026)\end{array}$ \\
\hline age & $\begin{array}{l}.015 \\
(.012)\end{array}$ & $\begin{array}{l}.004 \\
(.003)\end{array}$ & $\begin{array}{l}.032 \\
(.034)\end{array}$ & $\begin{array}{l}.008 \\
(.008)\end{array}$ \\
\hline age sq. & $\begin{array}{c}-.0003^{*} \\
(.0001)\end{array}$ & $\begin{array}{c}-.00007^{*} \\
(.00004)\end{array}$ & $\begin{array}{l}-.0004 \\
(.0004)\end{array}$ & $\begin{array}{l}-.0001 \\
(.0001)\end{array}$ \\
\hline educ. upper second. & $\begin{array}{c}-.140^{* *} \\
(.061)\end{array}$ & $\begin{array}{c}-.039^{* *} \\
(.0171)\end{array}$ & $\begin{array}{l}.111 \\
(.153)\end{array}$ & $\begin{array}{l}.0274 \\
(.038)\end{array}$ \\
\hline educ. tertiary & $\begin{array}{c}-.385^{* * *} \\
(.062)\end{array}$ & $\begin{array}{l}-.104^{* * *} \\
(.016)\end{array}$ & $\begin{array}{r}-.260^{*} \\
(.157)\end{array}$ & $\begin{array}{r}-.062^{*} \\
(.037)\end{array}$ \\
\hline ability1 & $\begin{array}{l}-.010 \\
(.089)\end{array}$ & $\begin{array}{l}-.003 \\
(.026)\end{array}$ & $\begin{array}{l}-.064 \\
(.229)\end{array}$ & $\begin{array}{l}-.016 \\
(.059)\end{array}$ \\
\hline ability2 & $\begin{array}{c}-.198^{* * *} \\
(.049)\end{array}$ & $\begin{array}{c}-.058^{* * *} \\
(.015)\end{array}$ & $\begin{array}{l}-.071 \\
(.126)\end{array}$ & $\begin{array}{l}-.018 \\
(.032)\end{array}$ \\
\hline unemployed & $\begin{array}{c}1.646^{* * *} \\
(.084)\end{array}$ & $\begin{array}{c}.586^{* * *} \\
(.026)\end{array}$ & & \\
\hline open end contract & $\begin{array}{c}-.394^{* * *} \\
(.044)\end{array}$ & $\begin{array}{c}-.119^{* * *} \\
(.014)\end{array}$ & $\begin{array}{c}-.756^{* * *} \\
(.121)\end{array}$ & $\begin{array}{c}-.227^{* * *} \\
(.041)\end{array}$ \\
\hline const. & $\begin{array}{c}-.606^{* *} \\
(.255)\end{array}$ & & $\begin{array}{l}-.649 \\
(.702)\end{array}$ & \\
\hline Controls for country fixed effects & yes & & yes & \\
\hline Obs. & 13573 & & 2262 & \\
\hline $\log -L$ & -5415.6 & & -753.8 & \\
\hline
\end{tabular}

Source: Computations based on ESS (2008). Notes: Uses ESS post-stratification weights combined with population size weights. Robust standard-errors in parenthesis. Columns 1 and 2 computed on the active population sample (employed and unemployed respondents) in the 16 countries under analysis; columns 3 and 4 computed on the analysis sample of employed workers. Marginal impacts computed the mean values and considering the change in each dummy variable from zero to one. 


\section{Appendix A: Computation of new weights}

Computation of any post-stratification weights requires auxiliary information on the actual distribution of the population, which is most often difficult to gather. Fortunately, in our case the original variable reported (income) encapsulates itself the distribution of the population - by definition, each decile of household income comprises 10 percent of the country's households. If the deciles shown respondents represent the true distribution of income and the surveyed population diverges from this distribution, we would want to correct the ESS weights to guarantee a uniform distribution of households across income deciles within each country. We have applied the procedure described in this section on the original dataset, before any data constraints were imposed.

Under the assumption that the population income deciles used by each national data producer indeed depict the actual distribution of the country's population, we face a common problem in survey handling - to compute weights when we know the true distribution of the population, but the survey distribution diverges from the actual one. We have therefore computed new weights that guarantee equal population shares across income deciles.

Take $N$ to be the size of the country's sampled population, with the known weight of a given income decile given by $\frac{N}{10}$. Let $s_{i d}$ be the survey sample weight of an individual $i$, whose income falls on decile $d$. The final adjusted weight for individual $i$ is thus given by

$$
f_{i d}=s_{i d} * c_{d}=s_{i d} * \frac{\frac{N}{10}}{\sum_{i \in d} s_{i d}} \quad \text { for } d=1, \ldots, 10 .
$$

Intuitively, the post-stratification correction factor for each decile, $c_{d}$, guarantees that deciles with "too much weight" in the survey dataset will have its weight corrected downwards and vice-versa (for a discussion on the computation of weights, see Groves et al. (2009) and Kalton (1983)).

Note that this uniform distribution refers to the distribution of the initial sample across household income deciles. The analysis sample includes only the working individuals and their earnings, and therefore it is expected to deviate from the uniform distribution. 


\section{Appendix B: Additional tables}

Table 5: Probability that the household reports its income, probit model

\begin{tabular}{|c|c|c|}
\hline & coef. & marg. impact \\
\hline Gender & $\begin{array}{l}-.049 \\
(.031)\end{array}$ & $\begin{array}{l}-.011 \\
(.007)\end{array}$ \\
\hline Age & $\begin{array}{c}.005^{* * *} \\
(.001)\end{array}$ & $\begin{array}{l}.001^{* * *} \\
(.0003)\end{array}$ \\
\hline $\begin{array}{l}\text { Activity } \\
\text { education }\end{array}$ & $\begin{array}{c}-.676^{* * *} \\
(.060)\end{array}$ & $\begin{array}{c}-.193^{* * *} \\
(.020)\end{array}$ \\
\hline unemployment & $\begin{array}{c}-.231^{* * *} \\
(.081)\end{array}$ & $\begin{array}{c}-.057^{* * *} \\
(.022)\end{array}$ \\
\hline other & $\begin{array}{l}-.213^{* * *} \\
(.047)\end{array}$ & $\begin{array}{c}-.049^{* * *} \\
(.011)\end{array}$ \\
\hline $\begin{array}{l}\text { Main source income } \\
\text { self-employment }\end{array}$ & $\begin{array}{c}-.166^{* * *} \\
(.063)\end{array}$ & $\begin{array}{c}-.040^{* * *} \\
(.016)\end{array}$ \\
\hline pensions & $\begin{array}{l}.057 \\
(.059)\end{array}$ & $\begin{array}{l}.012 \\
(.012)\end{array}$ \\
\hline social benefits & $\begin{array}{c}.465^{* * *} \\
(.082)\end{array}$ & $\begin{array}{c}.082^{* * *} \\
(.011)\end{array}$ \\
\hline other & $\begin{array}{c}-.615^{* * *} \\
(.064)\end{array}$ & $\begin{array}{c}-.177^{* * *} \\
(.022)\end{array}$ \\
\hline $\begin{array}{l}\text { Education } \\
\text { upper secondary }\end{array}$ & $\begin{array}{l}.111^{* * *} \\
(.037)\end{array}$ & $\begin{array}{c}.024^{* * *} \\
(.008)\end{array}$ \\
\hline tertiary & $\begin{array}{l}.184^{* * *} \\
(.042)\end{array}$ & $\begin{array}{c}.039^{* * *} \\
(.009)\end{array}$ \\
\hline Const. & $\begin{array}{c}.926^{* * *} \\
(.072)\end{array}$ & \\
\hline Obs. & 27857 & \\
\hline $\log -L$ & -10538.6 & \\
\hline
\end{tabular}

Source: Computations based on ESS (2008). Note: Uses ESS post-stratification weights combined with population size weights. Robust standard-errors in parenthesis. Computed on the initial ESS sample of 16 countries (see text, section 3), naturally including observations with both reported and missing income data. Marginal impacts computed at the mean values and considering the change in each dummy variable from zero to one. 
Table 6: Misperceptions of unemployment, interval regression

\begin{tabular}{lcc}
\hline & $(1)$ & $(2)$ \\
\hline educ. upper second. & $-4.179^{* * *}$ & $-4.063^{* * *}$ \\
educ. tertiary & $(.542)$ & $(.541)$ \\
& $-7.763^{* * *}$ & $-7.810^{* * *}$ \\
ability1 & $(.548)$ & $(.549)$ \\
& $-3.030^{* * *}$ & $-3.012^{* * *}$ \\
ability2 & $(.886)$ & $(.890)$ \\
& $-1.662^{* * *}$ & $-1.678^{* * *}$ \\
unemployed & $(.452)$ & $(.453)$ \\
& $5.604^{* * *}$ & $5.799^{* * *}$ \\
female & $(.758)$ & $(.755)$ \\
& $4.762^{* * *}$ & $4.786^{* * *}$ \\
age & $(.357)$ & $(.357)$ \\
& $-.514^{* * *}$ & $-.510^{* * *}$ \\
age sq. & $(.096)$ & $(.096)$ \\
& $.005^{* * *}$ & $.005^{* * *}$ \\
region. unempl. rate & $(.001)$ & $(.001)$ \\
diff. reg. and national unempl. rate (abs. value) & $.321^{* * *}$ & \\
& $(.058)$ & \\
const. & & $.237^{* *}$ \\
& & $(.098)$ \\
Obs. & $30.192^{* * *}$ & $31.857^{* * *}$ \\
Log $-L$ & $(2.119)$ & $(2.108)$ \\
$\sigma$ & 10506 & 10506 \\
& -31981.8 & -32000.9 \\
& 12.9 & 12.9 \\
\hline & &
\end{tabular}

Source: Computations based on ESS (2008). Notes: ability 1 equals one if the respondent understood the questions very often or often and zero otherwise; ability 2 equals one if the respondent never or almost never required clarifications on the questions and zero otherwise. Uses ESS post-stratification weights combined with population size weights. Robust standard-errors in parenthesis. Computed on the active population sample (employed and unemployed respondents) in the 12 countries with available data on regional unemployment rates. 
Table 7: Interval regression, (log) wages on (log) misperception of unemployment; including control for the regional unemployment rate

\begin{tabular}{|c|c|c|c|c|c|}
\hline & (1) & (2) & (3) & (4) & (5) \\
\hline (log) ratio misperc. unempl. & $\begin{array}{c}-.100^{* * *} \\
(.018)\end{array}$ & $\begin{array}{c}-.136^{* * *} \\
(.023)\end{array}$ & $\begin{array}{c}-.135^{* * *} \\
(.024)\end{array}$ & $\begin{array}{c}-.092^{* * *} \\
(.022)\end{array}$ & $\begin{array}{c}-.097^{* * *} \\
(.022)\end{array}$ \\
\hline (log) ratio misperc. unempl., if neg. & & $\begin{array}{c}.165^{* * *} \\
(.062)\end{array}$ & $\begin{array}{c}.164^{* * *} \\
(.063)\end{array}$ & $\begin{array}{l}.133^{* *} \\
(.061)\end{array}$ & $\begin{array}{l}.141^{* *} \\
(.063)\end{array}$ \\
\hline (log) regional unempl. rate & $\begin{array}{c}-.130^{* *} \\
(.051)\end{array}$ & $\begin{array}{c}-.127^{* *} \\
(.051)\end{array}$ & $\begin{array}{c}-.128^{* *} \\
(.050)\end{array}$ & $\begin{array}{c}-.102^{* *} \\
(.044)\end{array}$ & $\begin{array}{c}-.096^{* *} \\
(.043)\end{array}$ \\
\hline female & $\begin{array}{c}-.238^{* * *} \\
(.030)\end{array}$ & $\begin{array}{c}-.235^{* * *} \\
(.030)\end{array}$ & $\begin{array}{c}-.233^{* * *} \\
(.030)\end{array}$ & $\begin{array}{c}-.185^{* * *} \\
(.031)\end{array}$ & $\begin{array}{c}-.146^{* * *} \\
(.032)\end{array}$ \\
\hline age & $\begin{array}{c}.026^{* * *} \\
(.009)\end{array}$ & $\begin{array}{c}.025^{* * *} \\
(.009)\end{array}$ & $\begin{array}{c}.026^{* * *} \\
(.009)\end{array}$ & $\begin{array}{c}.019^{* *} \\
(.008)\end{array}$ & $\begin{array}{l}.012 \\
(.008)\end{array}$ \\
\hline age sq. & $\begin{array}{c}-.0002^{* *} \\
(.0001)\end{array}$ & $\begin{array}{c}-.0002^{* *} \\
(.0001)\end{array}$ & $\begin{array}{c}-.0002^{* *} \\
(.0001)\end{array}$ & $\begin{array}{l}-.0002^{*} \\
(.00009)\end{array}$ & $\begin{array}{l}-.0001 \\
(.0001)\end{array}$ \\
\hline educ. upper second. & $\begin{array}{c}.169^{* * *} \\
(.045)\end{array}$ & $\begin{array}{c}.158^{* * *} \\
(.046)\end{array}$ & $\begin{array}{c}.150^{* * *} \\
(.046)\end{array}$ & $\begin{array}{l}.047 \\
(.040)\end{array}$ & $\begin{array}{l}.051 \\
(.040)\end{array}$ \\
\hline educ. tertiary & $\begin{array}{c}.441^{* * *} \\
(.046)\end{array}$ & $\begin{array}{c}.429^{* * *} \\
(.046)\end{array}$ & $\begin{array}{c}.416^{* * *} \\
(.047)\end{array}$ & $\begin{array}{c}.181^{* * *} \\
(.046)\end{array}$ & $\begin{array}{c}.180^{* * *} \\
(.046)\end{array}$ \\
\hline ability1 & & & $\begin{array}{l}-.012 \\
(.087)\end{array}$ & $\begin{array}{l}-.069 \\
(.084)\end{array}$ & $\begin{array}{l}-.085 \\
(.087)\end{array}$ \\
\hline ability2 & & & $\begin{array}{l}.062^{*} \\
(.032)\end{array}$ & $\begin{array}{c}-.0009 \\
(.029)\end{array}$ & $\begin{array}{l}.011 \\
(.029)\end{array}$ \\
\hline firm size $100-500$ & & & & $\begin{array}{c}.069^{* *} \\
(.032)\end{array}$ & $\begin{array}{l}.057^{*} \\
(.031)\end{array}$ \\
\hline firm size $500+$ & & & & $\begin{array}{c}.126^{* * *} \\
(.039)\end{array}$ & $\begin{array}{c}.129^{* * *} \\
(.038)\end{array}$ \\
\hline part-timer & & & & $\begin{array}{c}-.175^{* * *} \\
(.052)\end{array}$ & $\begin{array}{c}-.189^{* * *} \\
(.049)\end{array}$ \\
\hline trade union member & & & & $\begin{array}{l}-.003 \\
(.031)\end{array}$ & $\begin{array}{l}.004 \\
(.031)\end{array}$ \\
\hline supervisor & & & & $\begin{array}{c}.114^{* * *} \\
(.029)\end{array}$ & $\begin{array}{c}.109^{* * *} \\
(.028)\end{array}$ \\
\hline open end contract & & & & $\begin{array}{c}.193^{* * *} \\
(.036)\end{array}$ & $\begin{array}{c}.174^{* * *} \\
(.036)\end{array}$ \\
\hline children below 16 (yes/no) & & & & & $\begin{array}{l}.043 \\
(.032)\end{array}$ \\
\hline partner & & & & & $\begin{array}{c}.182^{* * *} \\
(.041)\end{array}$ \\
\hline Const. & $\begin{array}{c}6.954^{* * *} \\
(.211)\end{array}$ & $\begin{array}{c}7.007^{* * *} \\
(.213)\end{array}$ & $\begin{array}{c}6.969^{* * *} \\
(.225)\end{array}$ & $\begin{array}{c}6.841^{* * *} \\
(.206)\end{array}$ & $\begin{array}{c}6.931^{* * *} \\
(.203)\end{array}$ \\
\hline \multicolumn{6}{|l|}{ Controls for: } \\
\hline country fixed effects & yes & yes & yes & yes & yes \\
\hline industry (4 dummies) & no & no & no & yes & yes \\
\hline occupation (3 dummies) & no & no & no & yes & yes \\
\hline Obs. & 1700 & 1700 & 1695 & 1673 & 1673 \\
\hline $\log -L$ & -3452.5 & -3447.4 & -3441.7 & -3207.2 & 3174.9 \\
\hline$\sigma$ & .411 & .410 & .410 & .364 & .356 \\
\hline
\end{tabular}

Source: Computations based on ESS (2008). Notes: The relative misperception index is computed according to equation 4 (i.e. the difference between $(\log )$ perceived unemployment rate and $(\log )$ actual unemployment rate in the country); in line 2, it is interacted with a dummy variable equal to one if the relative misperception index is negative and zero otherwise. Uses ESS post-stratification weights combined with population size weights. Robust standard-errors in parenthesis. 
Table 8: Interval regression, (log) wages on level of misperception of unemployment; including control for the regional unemployment rate (new weights)

\begin{tabular}{|c|c|c|c|c|c|}
\hline & (1) & $(2)$ & (3) & $(4)$ & $(5)$ \\
\hline misperception unemployment (abs value) & $\begin{array}{c}-.007^{* * *} \\
(.001)\end{array}$ & $\begin{array}{c}-.007^{* * *} \\
(.001)\end{array}$ & $\begin{array}{c}-.006^{* * *} \\
(.001)\end{array}$ & $\begin{array}{c}-.004^{* * *} \\
(.001)\end{array}$ & $\begin{array}{c}-.004^{* * *} \\
(.001)\end{array}$ \\
\hline misperc. unempl. if neg. (abs value) & & $\begin{array}{l}.010 \\
(.012)\end{array}$ & $\begin{array}{l}.010 \\
(.013)\end{array}$ & $\begin{array}{l}.003 \\
(.012)\end{array}$ & $\begin{array}{l}.003 \\
(.013)\end{array}$ \\
\hline (log) regional unempl. rate & $\begin{array}{c}-.117^{* *} \\
(.059)\end{array}$ & $\begin{array}{c}-.117^{* *} \\
(.059)\end{array}$ & $\begin{array}{c}-.119^{* *} \\
(.058)\end{array}$ & $\begin{array}{l}-.076 \\
(.049)\end{array}$ & $\begin{array}{l}-.069 \\
(.046)\end{array}$ \\
\hline female & $\begin{array}{c}-.259^{* * *} \\
(.034)\end{array}$ & $\begin{array}{c}-.258^{* * *} \\
(.034)\end{array}$ & $\begin{array}{c}-.257^{* * *} \\
(.034)\end{array}$ & $\begin{array}{c}-.210^{* * *} \\
(.037)\end{array}$ & $\begin{array}{c}-.162^{* * *} \\
(.037)\end{array}$ \\
\hline age & $\begin{array}{c}.030^{* * *} \\
(.011)\end{array}$ & $\begin{array}{c}.030^{* * *} \\
(.011)\end{array}$ & $\begin{array}{c}.031^{* * *} \\
(.011)\end{array}$ & $\begin{array}{c}.020^{* *} \\
(.009)\end{array}$ & $\begin{array}{l}.012 \\
(.009)\end{array}$ \\
\hline age sq. & $\begin{array}{c}-.0003^{* *} \\
(.0001)\end{array}$ & $\begin{array}{c}-.0003^{* *} \\
(.0001)\end{array}$ & $\begin{array}{c}-.0003^{* *} \\
(.0001)\end{array}$ & $\begin{array}{c}-.0002^{*} \\
(.0001)\end{array}$ & $\begin{array}{c}-.00009 \\
(.0001)\end{array}$ \\
\hline educ. upper second. & $\begin{array}{c}.163^{* * *} \\
(.052)\end{array}$ & $\begin{array}{c}.164^{* * *} \\
(.052)\end{array}$ & $\begin{array}{c}.157^{* * *} \\
(.052)\end{array}$ & $\begin{array}{l}.049 \\
(.042)\end{array}$ & $\begin{array}{l}.057 \\
(.042)\end{array}$ \\
\hline educ. tertiary & $\begin{array}{c}.442^{* * *} \\
(.050)\end{array}$ & $\begin{array}{c}.442^{* * *} \\
(.049)\end{array}$ & $\begin{array}{c}.432^{* * *} \\
(.050)\end{array}$ & $\begin{array}{c}.175^{* * *} \\
(.049)\end{array}$ & $\begin{array}{c}.176^{* * *} \\
(.049)\end{array}$ \\
\hline ability1 & & & $\begin{array}{l}-.022 \\
(.093)\end{array}$ & $\begin{array}{l}-.063 \\
(.088)\end{array}$ & $\begin{array}{l}-.078 \\
(.091)\end{array}$ \\
\hline ability 2 & & & $\begin{array}{l}.060^{*} \\
(.035)\end{array}$ & $\begin{array}{l}-.007 \\
(.031)\end{array}$ & $\begin{array}{l}.006 \\
(.032)\end{array}$ \\
\hline firm size $100-500$ & & & & $\begin{array}{c}.094^{* * *} \\
(.036)\end{array}$ & $\begin{array}{c}.079^{* *} \\
(.035)\end{array}$ \\
\hline firm size $500+$ & & & & $\begin{array}{c}.157^{* * *} \\
(.048)\end{array}$ & $\begin{array}{c}.159^{* * *} \\
(.046)\end{array}$ \\
\hline part-timer & & & & $\begin{array}{c}-.146^{* *} \\
(.067)\end{array}$ & $\begin{array}{c}-.166^{* * *} \\
(.060)\end{array}$ \\
\hline trade union member & & & & $\begin{array}{l}-.004 \\
(.038)\end{array}$ & $\begin{array}{l}.003 \\
(.037)\end{array}$ \\
\hline supervisor & & & & $\begin{array}{c}.103^{* * *} \\
(.035)\end{array}$ & $\begin{array}{c}.097^{* * *} \\
(.033)\end{array}$ \\
\hline open end contract & & & & $\begin{array}{c}.215^{* * *} \\
(.038)\end{array}$ & $\begin{array}{c}.196^{* * *} \\
(.037)\end{array}$ \\
\hline children below 16 (yes/no) & & & & & $\begin{array}{l}.056^{*} \\
(.034)\end{array}$ \\
\hline partner & & & & & $\begin{array}{c}.215^{* * *} \\
(.050)\end{array}$ \\
\hline Const. & $\begin{array}{c}6.776^{* * *} \\
(.247)\end{array}$ & $\begin{array}{c}6.771^{* * *} \\
(.247)\end{array}$ & $\begin{array}{c}6.747^{* * *} \\
(.260)\end{array}$ & $\begin{array}{c}6.671^{* * *} \\
(.233)\end{array}$ & $\begin{array}{c}6.768^{* * *} \\
(.228)\end{array}$ \\
\hline \multicolumn{6}{|l|}{ Controls for: } \\
\hline country fixed effects & yes & yes & yes & yes & yes \\
\hline industry (4 dummies) & no & no & no & yes & yes \\
\hline occupation (3 dummies) & no & no & no & yes & yes \\
\hline Obs. & 1700 & 1700 & 1695 & 1673 & 1673 \\
\hline $\log -L$ & -4155.8 & -4155.3 & -4149.0 & -3864.3 & -3813.6 \\
\hline$\sigma$ & .433 & .433 & .432 & .382 & .372 \\
\hline
\end{tabular}

Source: Computations based on ESS (2008). Notes: The misperception index is computed according to equation 3 (i.e. the difference between the perceived and the actual unemployment rate in the country); its absolute value is the regressor in line 1 ; in line 2 , the absolute value of the misperception index is interacted with a dummy variable equal to one if the misperception is negative and zero otherwise. Uses ESS post-stratification weights combined with population size weights. Robust standard-errors in parenthesis. 
Table 9: Ordered probit, (log) wages on level of misperception of unemployment

\begin{tabular}{|c|c|c|c|c|c|}
\hline & (1) & (2) & (3) & (4) & (5) \\
\hline misperception unemployment (abs value) & $\begin{array}{c}-.017^{* * *} \\
(.003)\end{array}$ & $\begin{array}{c}-.016^{* * *} \\
(.003)\end{array}$ & $\begin{array}{c}-.016^{* * *} \\
(.003)\end{array}$ & $\begin{array}{c}-.012^{* * *} \\
(.003)\end{array}$ & $\begin{array}{c}-.013^{* * *} \\
(.003)\end{array}$ \\
\hline misperc. unempl. if neg. (abs value) & & $\begin{array}{l}.031 \\
(.024)\end{array}$ & $\begin{array}{l}.031 \\
(.024)\end{array}$ & $\begin{array}{l}.010 \\
(.027)\end{array}$ & $\begin{array}{c}.010 \\
(.030)\end{array}$ \\
\hline female & $\begin{array}{c}-.570^{* * *} \\
(.068)\end{array}$ & $\begin{array}{c}-.568^{* * *} \\
(.068)\end{array}$ & $\begin{array}{c}-.564^{* * *} \\
(.069)\end{array}$ & $\begin{array}{c}-.500^{* * *} \\
(.078)\end{array}$ & $\begin{array}{c}-.402^{* * *} \\
(.084)\end{array}$ \\
\hline age & $\begin{array}{c}.058^{* * *} \\
(.021)\end{array}$ & $\begin{array}{c}.058^{* * *} \\
(.021)\end{array}$ & $\begin{array}{c}.060^{* * * *} \\
(.021)\end{array}$ & $\begin{array}{l}.048^{* *} \\
(.021)\end{array}$ & $\begin{array}{l}.030 \\
(.021)\end{array}$ \\
\hline age sq. & $\begin{array}{c}-.0005^{* *} \\
(.0002)\end{array}$ & $\begin{array}{c}-.0005^{* *} \\
(.0002)\end{array}$ & $\begin{array}{c}-.0006^{* *} \\
(.0002)\end{array}$ & $\begin{array}{c}-.0005^{*} \\
(.0002)\end{array}$ & $\begin{array}{l}-.0002 \\
(.0003)\end{array}$ \\
\hline educ. upper second. & $\begin{array}{c}.354^{* * *} \\
(.107)\end{array}$ & $\begin{array}{c}.357^{* * *} \\
(.107)\end{array}$ & $\begin{array}{c}.337^{* * *} \\
(.107)\end{array}$ & $\begin{array}{l}.109 \\
(.106)\end{array}$ & $\begin{array}{l}.127 \\
(.108)\end{array}$ \\
\hline educ. tertiary & $\begin{array}{c}1.023^{* * *} \\
(.112)\end{array}$ & $\begin{array}{c}1.024^{* * *} \\
(.112)\end{array}$ & $\begin{array}{c}.996^{* * *} \\
(.113)\end{array}$ & $\begin{array}{c}.491^{* * *} \\
(.120)\end{array}$ & $\begin{array}{c}.503^{* * *} \\
(.123)\end{array}$ \\
\hline ability1 & & & $\begin{array}{l}.010 \\
(.201)\end{array}$ & $\begin{array}{l}-.137 \\
(.219)\end{array}$ & $\begin{array}{l}-.184 \\
(.231)\end{array}$ \\
\hline ability2 & & & $\begin{array}{l}.128^{*} \\
(.075)\end{array}$ & $\begin{array}{l}-.024 \\
(.077)\end{array}$ & $\begin{array}{l}.004 \\
(.078)\end{array}$ \\
\hline firm size $100-500$ & & & & $\begin{array}{l}.207^{* *} \\
(.083)\end{array}$ & $\begin{array}{c}.180^{* *} \\
(.082)\end{array}$ \\
\hline firm size $500+$ & & & & $\begin{array}{c}.347^{* * *} \\
(.101)\end{array}$ & $\begin{array}{c}.362^{* * *} \\
(.100)\end{array}$ \\
\hline part-timer & & & & $\begin{array}{c}-.484^{* * *} \\
(.136)\end{array}$ & $\begin{array}{c}-.531^{* * *} \\
(.131)\end{array}$ \\
\hline trade union member & & & & $\begin{array}{c}.055 \\
(.078)\end{array}$ & $\begin{array}{l}.075 \\
(.079)\end{array}$ \\
\hline supervisor & & & & $\begin{array}{c}.319^{* * *} \\
(.076)\end{array}$ & $\begin{array}{c}.309^{* * *} \\
(.075)\end{array}$ \\
\hline open end contract & & & & $\begin{array}{c}.537^{* * *} \\
(.095)\end{array}$ & $\begin{array}{c}.499^{* * *} \\
(.096)\end{array}$ \\
\hline children below 16 (yes/no) & & & & & $\begin{array}{l}.130 \\
(.087)\end{array}$ \\
\hline partner & & & & & $\begin{array}{c}.497^{* * *} \\
(.109)\end{array}$ \\
\hline \multicolumn{6}{|l|}{ Controls for: } \\
\hline country fixed effects & yes & yes & yes & yes & yes \\
\hline industry (4 dummies) & no & no & no & yes & yes \\
\hline occupation (3 dummies) & no & no & no & yes & yes \\
\hline Obs. & 2310 & 2310 & 2299 & 2263 & 2263 \\
\hline $\log -L$ & -3589.2 & -3588.4 & -3582.3 & -3335.0 & -3301.6 \\
\hline
\end{tabular}

Source: Computations based on ESS (2008). Notes: The misperception index is computed according to equation 3 (i.e. the difference between the perceived and the actual unemployment rate in the country); its absolute value is the regressor in line 1 ; in line 2 , the absolute value of the misperception index is interacted with a dummy variable equal to one if the misperception is negative and zero otherwise. Uses ESS post-stratification weights combined with population size weights. Robust standard-errors in parenthesis. 
Table 10: Ordered probit, (log) wages on level of misperception of unemployment; including control for the regional unemployment rate

\begin{tabular}{|c|c|c|c|c|c|}
\hline & (1) & $(2)$ & (3) & (4) & $(5)$ \\
\hline misperception unemployment (abs value) & $\begin{array}{c}-.017^{* * *} \\
(.003)\end{array}$ & $\begin{array}{c}-.016^{* * *} \\
(.003)\end{array}$ & $\begin{array}{c}-.016^{* * *} \\
(.003)\end{array}$ & $\begin{array}{c}-.012^{* * *} \\
(.003)\end{array}$ & $\begin{array}{c}-.013^{* * *} \\
(.003)\end{array}$ \\
\hline misperc. unempl. if neg. (abs value) & & $\begin{array}{l}.034 \\
(.027)\end{array}$ & $\begin{array}{l}.034 \\
(.027)\end{array}$ & $\begin{array}{l}.010 \\
(.030)\end{array}$ & $\begin{array}{l}.010 \\
(.033)\end{array}$ \\
\hline (log) regional unempl. rate & $\begin{array}{c}-.304^{* *} \\
(.126)\end{array}$ & $\begin{array}{c}-.305^{* *} \\
(.126)\end{array}$ & $\begin{array}{c}-.307^{* *} \\
(.125)\end{array}$ & $\begin{array}{c}-.274^{* *} \\
(.123)\end{array}$ & $\begin{array}{c}-.263^{* *} \\
(.120)\end{array}$ \\
\hline female & $\begin{array}{c}-.573^{* * *} \\
(.071)\end{array}$ & $\begin{array}{c}-.570^{* * *} \\
(.071)\end{array}$ & $\begin{array}{c}-.566^{* * *} \\
(.071)\end{array}$ & $\begin{array}{c}-.502^{* * *} \\
(.082)\end{array}$ & $\begin{array}{c}-.409^{* * *} \\
(.087)\end{array}$ \\
\hline age & $\begin{array}{c}.058^{* * *} \\
(.022)\end{array}$ & $\begin{array}{c}.058^{* * *} \\
(.022)\end{array}$ & $\begin{array}{c}.060^{* * *} \\
(.022)\end{array}$ & $\begin{array}{c}.049^{* *} \\
(.022)\end{array}$ & $\begin{array}{l}.030 \\
(.023)\end{array}$ \\
\hline age sq. & $\begin{array}{c}-.0005^{* *} \\
(.0003)\end{array}$ & $\begin{array}{c}-.0005^{* *} \\
(.0003)\end{array}$ & $\begin{array}{c}-.0006^{* *} \\
(.0003)\end{array}$ & $\begin{array}{c}-.0005^{*} \\
(.0003)\end{array}$ & $\begin{array}{l}-.0002 \\
(.0003)\end{array}$ \\
\hline educ. upper second. & $\begin{array}{c}.367^{* * *} \\
(.114)\end{array}$ & $\begin{array}{c}.372^{* * *} \\
(.114)\end{array}$ & $\begin{array}{c}.354^{* * *} \\
(.113)\end{array}$ & $\begin{array}{l}.115 \\
(.112)\end{array}$ & $\begin{array}{l}.131 \\
(.114)\end{array}$ \\
\hline educ. tertiary & $\begin{array}{c}1.033^{* * *} \\
(.118)\end{array}$ & $\begin{array}{c}1.035^{* * *} \\
(.118)\end{array}$ & $\begin{array}{c}1.010^{* * *} \\
(.118)\end{array}$ & $\begin{array}{c}.500^{* * *} \\
(.126)\end{array}$ & $\begin{array}{c}.510^{* * *} \\
(.130)\end{array}$ \\
\hline ability1 & & & $\begin{array}{l}-.019 \\
(.211)\end{array}$ & $\begin{array}{l}-.163 \\
(.228)\end{array}$ & $\begin{array}{l}-.211 \\
(.241)\end{array}$ \\
\hline ability 2 & & & $\begin{array}{l}.129^{*} \\
(.078)\end{array}$ & $\begin{array}{l}-.025 \\
(.080)\end{array}$ & $\begin{array}{l}.005 \\
(.082)\end{array}$ \\
\hline firm size $100-500$ & & & & $\begin{array}{l}.207^{* *} \\
(.086)\end{array}$ & $\begin{array}{c}.177^{* *} \\
(.085)\end{array}$ \\
\hline firm size $500+$ & & & & $\begin{array}{c}.342^{* * *} \\
(.104)\end{array}$ & $\begin{array}{c}.357^{* * *} \\
(.103)\end{array}$ \\
\hline part-timer & & & & $\begin{array}{c}-.490^{* * *} \\
(.142)\end{array}$ & $\begin{array}{c}-.541^{* * *} \\
(.137)\end{array}$ \\
\hline trade union member & & & & $\begin{array}{l}.032 \\
(.083)\end{array}$ & $\begin{array}{l}.051 \\
(.084)\end{array}$ \\
\hline supervisor & & & & $\begin{array}{c}.306^{* * *} \\
(.079)\end{array}$ & $\begin{array}{c}.298^{* * *} \\
(.078)\end{array}$ \\
\hline open end contract & & & & $\begin{array}{c}.556^{* * *} \\
(.101)\end{array}$ & $\begin{array}{c}.515^{* * *} \\
(.102)\end{array}$ \\
\hline children below 16 (yes/no) & & & & & $\begin{array}{l}.144 \\
(.090)\end{array}$ \\
\hline partner & & & & & $\begin{array}{c}.488^{* * *} \\
(.114)\end{array}$ \\
\hline \multicolumn{6}{|l|}{ Controls for: } \\
\hline country fixed effects & yes & yes & yes & yes & yes \\
\hline industry (4 dummies) & no & no & no & yes & yes \\
\hline occupation (3 dummies) & no & no & no & yes & yes \\
\hline Obs. & 1700 & 1700 & 1695 & 1673 & 1673 \\
\hline $\log -L$ & -3420.7 & -3419.8 & -3414.9 & -3177.1 & -3145.1 \\
\hline
\end{tabular}

Source: Computations based on ESS (2008). Notes: The misperception index is computed according to equation 3 (i.e. the difference between the perceived and the actual unemployment rate in the country); its absolute value is the regressor in line 1 ; in line 2 , the absolute value of the misperception index is interacted with a dummy variable equal to one if the misperception is negative and zero otherwise. Uses ESS post-stratification weights combined with population size weights. Robust standard-errors in parenthesis. 
Table 11: Marginal effects ordered probit, (log) wages on level of misperception of unemployment

\begin{tabular}{ccccccccccc} 
& interval1 & interval2 & interval3 & interval4 & interval5 & interval6 & interval7 & interval8 & interval9 & interval10 \\
\hline \hline (1) & 0.00077 & 0.00207 & 0.00248 & 0.00130 & -0.00020 & -0.00100 & -0.00154 & -0.00150 & -0.00124 & -0.00113 \\
& 0.00017 & 0.00037 & 0.00046 & 0.00027 & 0.00009 & 0.00021 & 0.00030 & 0.00030 & 0.00024 & 0.00024 \\
$(2)$ & 0.00075 & 0.00201 & 0.00241 & 0.00126 & -0.00020 & -0.00098 & -0.00150 & -0.00146 & -0.00120 & -0.00110 \\
& 0.00017 & 0.00037 & 0.00047 & 0.00027 & 0.00009 & 0.00021 & 0.00030 & 0.00030 & 0.00024 & 0.00024 \\
$(3)$ & 0.00074 & 0.00199 & 0.00240 & 0.00126 & -0.00019 & -0.00097 & -0.00149 & -0.00145 & -0.00120 & -0.00109 \\
& 0.00017 & 0.00037 & 0.00047 & 0.00027 & 0.00009 & 0.00021 & 0.00030 & 0.00030 & 0.00024 & 0.00023 \\
$(4)$ & 0.00031 & 0.00128 & 0.00199 & 0.00110 & -0.00021 & -0.00088 & -0.00125 & -0.00108 & -0.00074 & -0.00051 \\
& 0.00010 & 0.00034 & 0.00054 & 0.00031 & 0.00009 & 0.00025 & 0.00034 & 0.00030 & 0.00020 & 0.00015 \\
(5) & 0.00030 & 0.00135 & 0.00216 & 0.00118 & -0.00028 & -0.00099 & -0.00136 & -0.00113 & -0.00075 & -0.00048 \\
& 0.00009 & 0.00034 & 0.00056 & 0.00032 & 0.00011 & 0.00027 & 0.00036 & 0.00030 & 0.00019 & 0.00014
\end{tabular}

Source: Computations based on ESS (2008). Robust standard-errors in italics. Each line (labeled from (1) to (5) ) corresponds to the equivalent model specification reported in table 9 .

Table 12: Marginal effects ordered probit, (log) wages on level of misperception of unemployment; including control for the regional unemployment rate

\begin{tabular}{|c|c|c|c|c|c|c|c|c|c|c|}
\hline & interval1 & interval2 & interval3 & interval4 & interval5 & interval6 & interval7 & interval8 & interval9 & interval10 \\
\hline \multirow[t]{2}{*}{ (1) } & 0.00076 & 0.00206 & 0.00245 & 0.00131 & -0.00017 & -0.00095 & -0.00152 & -0.00150 & -0.00128 & -0.00116 \\
\hline & 0.00017 & 0.00038 & 0.00048 & 0.00028 & 0.00010 & 0.00021 & 0.00031 & 0.00031 & 0.00025 & 0.00025 \\
\hline \multirow[t]{2}{*}{ (2) } & 0.00073 & 0.00199 & 0.00238 & 0.00127 & -0.00016 & -0.00092 & -0.00147 & -0.00145 & -0.00124 & -0.00113 \\
\hline & 0.00017 & 0.00038 & 0.00048 & 0.00028 & 0.00010 & 0.00021 & 0.00031 & 0.00031 & 0.00025 & 0.00025 \\
\hline \multirow[t]{2}{*}{ (3) } & 0.00072 & 0.00198 & 0.00237 & 0.00127 & -0.00016 & -0.00092 & -0.00147 & -0.00145 & -0.00123 & -0.00111 \\
\hline & 0.00017 & 0.00038 & 0.00048 & 0.00028 & 0.00010 & 0.00020 & 0.00031 & 0.00031 & 0.00025 & 0.00025 \\
\hline \multirow[t]{2}{*}{ (4) } & 0.00030 & 0.00129 & 0.00198 & 0.00111 & -0.00019 & -0.00085 & -0.00125 & -0.00109 & -0.00078 & -0.00052 \\
\hline & 0.00010 & 0.00035 & 0.00055 & 0.00032 & 0.00010 & 0.00025 & 0.00035 & 0.00032 & 0.00021 & 0.00016 \\
\hline \multirow[t]{2}{*}{ (5) } & 0.00030 & 0.00136 & 0.00216 & 0.00119 & -0.00026 & -0.00096 & -0.00137 & -0.00115 & -0.00079 & -0.00049 \\
\hline & 0.00009 & 0.00035 & 0.00057 & 0.00033 & 0.00012 & 0.00027 & 0.00037 & 0.00032 & 0.00020 & 0.00014 \\
\hline
\end{tabular}

Source: Computations based on ESS (2008). Robust standard-errors in italics. Each line (labeled from (1) to (5)) corresponds to the equivalent model specification reported in table 10. 